\title{
Architecture at the Outfalls Sixteen Constructions for the Ottawa River
}

\author{
by \\ Julien Hebert
}

\begin{abstract}
A thesis submitted to the Faculty of Graduate and Post-Doctoral Affairs in partial fulfillment of the requirements for the degree of
\end{abstract}

Master of Architecture

Carleton University,

Ottawa, Ontario 


\begin{abstract}
This thesis considers the architectural potential of hidden hydraulic systems and the cycle of water within cities with a view to acknowledging water's invisible, yet essential movements through an urban area. A combined sewage system dating from the late 19th century in older parts of Ottawa causes untreated wastewater to be discharged directly into the river at sixteen locations. Architecture at the Outfalls proposes the design of sixteen habitable spaces at these locations to materialize the collision of hidden hydraulic infrastructures and everyday paths, and engineering systems and the public realm. The architectural interventions also reveal water as an essential resource for living, and the Ottawa River as a visible, topographical, and spatial element in urban life.
\end{abstract}




\section{Acknowledgements}

I would like to express my deep gratitude to my supervisor Janine Debanné, whose expertise, understanding, and generous guidance were invaluable to me through the learning process and writing of this master thesis. Furthermore I would like to thank Paul Kariouk for guidance in the early stages of this thesis. I would also like to thank my loved ones, who have given me the support I needed throughout the entire process. 


\section{Table of Contents}

$\begin{array}{ll}\text { ii } & \text { Abstract } \\ \text { iii } & \text { Acknowledgements } \\ \text { iv } & \text { Table of Contents } \\ \text { v } & \text { List of Figures } \\ \text { vi } & \text { List of Appendices }\end{array}$

$1 \quad$ Introduction

3 Chapter 1 - The Hiddenness of Urban Water

10 Chapter 2 - Urban Waterfront Edges

15 Chapter 3 - Water Architectures

18 Chapter 4 - The Typology of Small Outdoor Buildings

20 Chapter 5 - Ottawa's Purified Water and Problematic Sewers

24 Chapter 6 - Architecture at the Outfalls

$58 \quad$ Conclusion

$60 \quad$ Appendices

80 Bibliography 


\section{List of Figures}

$27 \quad$ Figure 1 - Lemieux Public Washroom

29 Figure 2 - The Prince of Wales Tackle Shop

31 Figure 3 - Vigneau's Gallery (Artwork of the River by Local Artists)

33 Figure $4-$ Whitewater Brewing Co. Bistro

35 Figure 5 - Supreme Court Bridge

37 Figure 6 - The Ottawa Waterways Museum

39 Figure 7 - Monument for Loggers (The J.R. Booth Pavilion)

41 Figure 8 - The Hockey Sweater (The Macdonald-Cartier Bilingual Library)

$43 \quad$ Figure 9 - The Rideau Fountain

$45 \quad$ Figure $10-$ The Rural Well

47 Figure 11 - The Rockcliffe Wedding Pavilion

49 Figure 12 - The New Edinburgh Boat Launch

51 Figure 13 - The RCMP Stables (Horse Shelter and Trough)

53 Figure 14 - Canadian Aviation Museum Helipad

55 Figure 15 - The Beacon Hill Rock Pool

57 Figure 16 - The Ottawa River Wetlands 


\section{List of Appendices}

60 Appendix 1 - Sixteen map panels showing the location of the sixteen outfalls

61 Appendix 2 - Single map panel with lasercut lines

62 Appendix 3 - Detail of lasercut map panel

62 Appendix $4-$ Detail of lasercut map panel

63 Appendix 5 - Detail of lasercut map panel

63 Appendix 6 - Detail of lasercut map panel

64 Appendix 7 - Construction 1 Model

65 Appendix 8-Construction 2 Model

66 Appendix 9-Construction 3 Model

67 Appendix $10-$ Construction 4 Model

68 Appendix $11-$ Construction 5 Model

69 Appendix 12 - Construction 6 Model

70 Appendix $13-$ Construction 7 Model

71 Appendix $14-$ Construction 8 Model

72 Appendix 15 - Construction 9 Model

73 Appendix $16-$ Construction 10 Model

74 Appendix $17-$ Construction 11 Model

75 Appendix $18-$ Construction 12 Model

76 Appendix $19-$ Construction 13 Model

77 Appendix $20-$ Construction 14 Model

78 Appendix $21-$ Construction 15 Model

79 Appendix $22-$ Construction 16 Model 


\section{Introduction}

"Here, no more false appearance, no possible plastering, the filth takes off its shirt, absolute nakedness, rout of illusions and of mirages, nothing more but what it is ... The last veil is rent. A sewer is a cynic. It tells all." 1

- Victor Hugo, Les Misérables, Volume Two

Water appears in cities in the form of puddles and roadside run-off. During storms or thaws, water's presence is amplified, but most city dwellers know little about water's movements beneath the street surface. In this sense, water moves through cities invisibly, and yet citizens would gain from knowing more about the hydraulic paths, and by understanding their city as a watershed. If we could see the processes that captured and guided rainwater and divided and distributed potable and non-potable water, if we could perceive the city as a watershed, we might become more thoughtful in how we articulate the city's surfaces on the ground.

This thesis considers the architectural potential of hidden hydraulic systems and the cycle of water within cities, with a view to acknowledging water's invisible yet essential movements through an urban area. Baron Haussmann's project for the modernization of Paris remains to this day a memorable example of the conceptualization of the modern city as a necessarily double system: the city above and the one below. Haussmann's beautiful modern city of axial streets and parks was underpinned by an elaborate new sewer system that carefully calibrated the balance of urban waters. This infrastructure served a pragmatic purpose, yet influenced the form of the urban fabric above.

\footnotetext{
${ }^{1}$ Hugo, Victor. Les Misérables Volume Two. Woodsworth Editions Limited. 1994. p.858.
} 
This thesis, set in Ottawa, delves into the realm of intersection between hidden and visible city. Today, in Canada's capital, this relationship poses a very interesting question because the two systems - the surface of the city and the gutter and water main network - operate in a kind of unresolved conflict. In Ottawa, the cycle of purifying water and returning wastewater to the river is not without fault. A combined sewage system dating from the late $19^{\text {th }}$ century in older parts of the city causes untreated wastewater to be discharged directly into the river at sixteen locations. This unfortunate event happens during the wet seasons, when rainfall exceeds the city's only wastewater plant's capacity. This problem, an embarrassing one for a new world capital city in a country defined by its natural resources and fresh water reserves, invites deeper reflection on the environmental impact of cities and the act of dwelling.

More specifically, this thesis pursues a project of architectural interventions along the Ottawa River, at the aforementioned sixteen outfalls where dirty urban water overflows into the river. "Here, no more false appearance," to borrow Hugo's words, and "nothing more" than what they are: these sixteen points invite honest reckoning with the impact of our urban life on the Ottawa River. Architecture at the Outfalls unfolds a fine-grained expression of the city's broader hydraulic system and acknowledges the infrastructural issues the city faces while bringing public activity to the waterfront. Conceived as sitespecific pavilions that respond to adjacencies and everyday patterns of life, these constructions are topographical devices. Finally, they bring visitors closer to the limit of the urban realm, to the very place where the city returns to water: the shores of the Ottawa River. 


\section{Chapter 1 - The Hiddenness of Urban Water}

'Eventually I became able to 'sense' the water system. Sometimes, it was because of the way the road was paved, or the type of fencing along the roadway." 2

- Stanley Greenberg, Waterworks: A Photographic Journey Through New York's Hidden Water System

In Waterworks: A Photographic Journey Through New York's Hidden Water System, Stanley Greenberg photographed some of New York's infrastructural underground spaces between 1992 and 2001, just before the events of 9/11 closed most of these sites to all access. ${ }^{3}$ Greenberg's statement about learning to sense the water system is telling: he received an education on the visible city from spending years studying the invisible city of infrastructures. The invisible systems of the city can be revealed in subtle ways on the urban fabric above it.

Water is fundamental to life; we require it to survive. Yet in our Canadian cities, few still draw daily water from wells or carry water from sources to homes. This precious resource is administered to us and we receive it passively, in order to consume it. Our understanding of what is involved to get clean water into our homes, workplaces, and places of leisure, is limited. With millions of liters rushing under our streets daily, the flow of urban water remains a 'hidden' process. The city's kilometers of underground infrastructure serve a pragmatic purpose and are important to the population's health, yet people remain disconnected from these systems, ignorant of their effect upon the natural

\footnotetext{
${ }^{2}$ Greenberg, Stanley. Waterworks: A Photographic Journey Through New York's Hidden Water System. Princeton Architectural Press. New York. 2003. p.3.

${ }^{3}$ Ibid. p.2-3.
} 
watershed. As in many cities, Ottawa's purification and wastewater treatment plants are typically hidden away from the public, operating as industrial fortresses. The massive underground systems that distribute water to the public and waste to the treatment plant roar silently under the streets. Ottawa citizens use and rely on the Ottawa River, the city's sole source of fresh water, as a resource in everyday life. Yet, with few tangible expressions of water's workings in the built fabric, it is not easy for them to become aware of the impact of their own actions on the river, nor, more generally, of the effects of urbanisation upon the natural environment. Hydraulic patterns and systems merit being more legible. Moreover, there is much to be gained from making water visible.

Combined sewers in many cities including Canada's capital are responsible for the event of untreated wastewater being dumped into natural bodies of water. This unfortunate sequence results in the poisoning of rivers and the water table, with direct consequences upon the local population and ecology, most notably, beach closures in the summer (signalled by the raising of red flags on the beaches). Combined sewage overflow (CSO) is a recurring problem in the Nation's Capital, and like many cities in similar positions, Ottawa plans to build underground storage tanks and tunnels to capture storm overflow, and time its flow to the treatment plant. ${ }^{4}$ This solution is an expensive one. What is more, it does not contribute in any way to making the problem of holding back storm water to preserve the salubrity of our rivers - such a crucial issue for Ottawans in the summer visible. And yet, another, much less expensive solution would have been possible, but the

\footnotetext{
${ }^{4}$ Combined Sewage Storage - Environmental Study Report. City of Ottawa. Stantec. 8 Jan 2013.
} 
very reason that the City did not opt for it was that it was a "visible" one. These hidden storage tanks mimic the structures of the grids and streets above them, yet remain buried.

The “Combined Sewer Overflow Storage Environmental Assessment and Functional Design Project" is one of seventeen projects of the Ottawa River Action Plan and is currently ongoing. Soon to be constructed, this project identified and developed a preferred solution to the problem of additional storage of combined sewage in the combined sewer area of the city (older neighbourhoods) and thereby reduce combined sewer overflows into the Ottawa River. Representatives from Stantec, the project engineers, explain that the project "hopes to reduce CSOs from the Ultimate Combined Sewer Area and improve the water quality of the Ottawa River." ${ }^{5}$ Stantec's feasibility study considered many alternatives including storage tanks, storage shafts, short and long tunnels of various alignments, combinations of tanks and tunnels, and finally, in-river storage. ${ }^{6}$ The City of Ottawa and Stantec's preferred solution was the one comprised of storage tunnels. Yet, this solution has no visual impact and won't inform the public about the use of water in their city.

One of the alternative solutions was In-River Storage. This "Dunker system" solution relies on an in-river storage system that would involve a bladder-like enclosure near the three existing main outfalls. The enclosure would be suspended by buoys, or floats, that would be installed during the control period. The system would temporarily store

\footnotetext{
${ }^{5}$ Project Overview. Combined Sewer Overflow (CSO) Storage Environmental Assessment and Functional Design Project. City of Ottawa. 2015.

${ }^{6}$ Combined Sewage Storage - Environmental Study Report. City of Ottawa. Stantec. 8 Jan 2013. Section 2.3.
} 
combined sewage to prevent an overflow and, significantly, would be visible at the surface. After the rainfall and overflow event, the sewage would be pumped back to the wastewater treatment plant in stages. ${ }^{7}$ This solution would encompass the shortest implementation time and be the most cost effective due to its modest infrastructural needs, but it was not given much consideration for a few reasons. Firstly, "the approval needs for this unusual system would likely be quite onerous and approval of this alternative is not a given considering the potential environmental and socio-cultural impacts to the Ottawa River". ${ }^{8}$ Secondly, this solution also was the only one that had a visual impact on the shoreline. The City considered this to be significant. Finally, since one of the outfalls is located near the Rideau Canal, a UNESCO World Heritage Site, there would also be serious heritage considerations to contend with. ${ }^{9}$

This option was not shortlisted during the environmental assessment. The main reason for this is it had the highest environmental and socio-cultural impact. Stantec's feasibility report deemed the more typical tunnel/underground storage tank solution to have the lowest visual impact and therefore recommended it. Yet hiding key infrastructural elements from the public fails to achieve an important goal: to educate the public about vital hydraulic processes and render them more visible. Hydraulic infrastructures that are more visible to the public can become tangible symbols for how cities affect their natural surroundings. A proposition for a series of architectural interventions at the threshold between infrastructure and the public realm will be presented in Chapter 6 .

\footnotetext{
${ }^{7}$ Alternate Solution 5 - Dunker's System. Open House March/April 2009. City of Ottawa. 2009.

${ }^{8}$ Combined Sewage Storage - Environmental Study Report. City of Ottawa. Stantec. 8 Jan 2013. Section 3.4.2.

${ }^{9}$ Ibid. Section 3.6
} 
The question of hiddenness and expression of systems has preoccupied architects.

Infrastructures are to cities what structures are to buildings. These underground veins serve a pragmatic purpose, as do the structural systems of a building. Structural elements in a building can be hidden, and often are. "In these methods of concealing structural systems, where some members are exposed and others hidden, the structural system is partially hidden and thereby likely to be incomprehensible." ${ }^{10}$ Structural expressionism in the twentieth century allowed architects to reveal the structures of their buildings and to create a new clarity of design that accepted technological realities as valid and worthy of recognition. Perhaps most notable of these buildings was Renzo Piano and Richard Roger's Centre George Pompidou, with engineer Peter Rice (1972), which took the idea of exposing architectural systems to an extreme point. The remarkable building notably exposed all its systems, painting each one in a different, bright colour. Plumbing pipes were green. Exposing and colour coding the systems made all the building's underlying pragmatic objectives clearly legible. The arts centre, through programmatic elements, marries daily urban activity to the functions of the building. The building is also expressed as a node that connects to the city's larger hydraulic system. The clarity of the systems within the building allow visitors to see how the architecture is attached to the city, while a popular fountain outside the building further unites public function with water systems. This clarity of design and its idea of revealing and constructing beauty out of what are normally messy and hidden systems of architecture, are key principles to underscore here.

\footnotetext{
${ }^{10}$ Charleson, Andrew. Structure as Architecture: A Source Book for Architects and Structural Engineers. Elsevier/Architectural Press. 2005. P.162.
} 
Gordon Matta-Clark's "Anarchitecture" was fascinated with the idea of revealing invisible spaces. In particular, his work was fascinated with the opportunity presented by buildings about to be demolished, to reveal previously impossible connections. While his interventions did not all specifically deal with water, they were preoccupied with revealing the city in new and unforeseen ways, by his famous deconstructive cuts. The artist trained in architecture worked on what he referred to as "Anarchitecture", a word built form the words anarchy and architecture. ${ }^{11}$ In his final major project, titled Circus or The Caribbean Orange, he made large circular cuts into an existing townhouse, revealing the architectural systems hidden within. ${ }^{12}$ This act of cutting, or dissecting, was a form of rejection of architecture. Thanks to a fellowship from the John Simon Guggenheim Memorial Foundation, Matta-Clark was able to pursue his interest in the inner workings underneath the visible city in 1977, when he filmed and photographed tunnels, sewers, and catacombs in New York and Paris. Curator Jessamyn Fiore states:

"In all of his work, he was proposing a different kind of architecture, a
new relationship to our urban environment. I think he was trying to
show that we should look at what's in front of us and how people live
and what we waste, not only to better our city but to better the way
that people live in the city.",

His political and often controversial projects criticised "master plans" and he "proposed that more could be learned by closely observing the urban environment as it was than imposing grand plans upon it." ${ }^{14}$ Architecture at the Outfalls explores architectural strategies that attempt to "unhide" not only the tangible infrastructure itself, but also aims

\footnotetext{
${ }^{11}$ Attlee, James. Towards Anarchitecture: Gordon Matta-Clark and Le Corbusier. Tate Papers no.7. 2007.

${ }^{12}$ M. Lee, Pamela. Object to be Destroyed: The Work of Gordon Matta-Clark. MIT Press. 2001. P.145.

${ }^{13}$ Murg, Stephanie. Gordon Matta-Clark: Cutting through History. Metropolis. 10 Aug 2013.

${ }^{14}$ Attlee, James. Towards Anarchitecture: Gordon Matta-Clark and Le Corbusier. Tate Papers no.7. 2007.
} 
to make understandable Ottawa's sewer system as territory of political debate in Ottawa. Matta Clark's language of strategically placed cuts informs the architecture of the sixteen propositions in this thesis, as will be seen further on. 


\section{Chapter 2 - Urban Waterfront Edges}

"Everywhere I walked on the waterfront, I saw the present as a layered accumulation of older narratives. I tried to read the city as a text." 15

- Phillip Lopate, Waterfront: A Walk Around Manhattan

In the early 2000s, Phillip Lopate walked every inch of the Manhattan shoreline. In his book Waterfront: A Walk Around Manhattan, he explores the heritage of the waterfront from a rich industrial port, and appraises today's developers and environmental activists, while investigating new plans for parks and pleasure domes with river views. He gives a critical opinion of the changing waterfronts within cities.

The pre-industrial city had a close relationship with the waterfront. They were "intensely used and thriving with people and activities". ${ }^{16}$ During the industrial period, this connection to the river made way for industry's ports, warehouses, and transportation. Following the industrial revolution, commercial activity moved away from city centers for various reasons such as changes in transportation modes, the increased efficiency of distributing electricity, and containerization technology. This led to large polluted areas in cities being abandoned and unused. "In the past thirty years or so, these properties have become recognized as prime property for redevelopment across the United States and abroad." 17

\footnotetext{
${ }^{15}$ Lopate, Phillip. Waterfront: A Walk Around Manhattan. Knopf Doubleday Publishing Group. New York. 2008. p.5.

${ }^{16}$ Timur, Umut Pekin. Urban Waterfront Regenerations. Advances in Landscape Architecture. Chapter 7. Çankırı Karatekin University, Faculty of Forestry. 1 Jul 2013. P.169.

${ }^{17}$ Ryckbost, Paul. Redeveloping Urban Waterfront Property. 14 April 2005.
} 
Listed as "the model for post-industrial waterfront redevelopment around the world" by the Urban Land Institute, Baltimore's Inner Harbour stands as a prime example of cities' move towards rediscovering the waterfront as a place for leisure, parkland, and rest. ${ }^{18}$ The catalyst for this renewal was the earlier Charles Center redevelopment of a downtown district in decline, and for which the master-plan was unveiled publicly in 1958. The project, which took several years to complete, would include a tower by Mies van der Rohe. ${ }^{19}$ Designed to reduce the decline in property value at the waterfront, it was an urban redevelopment success. By now, "the shipping industry had completely abandoned the Inner Harbor, [...] there was an opportunity crying out for new users to capitalize on the waterfront's natural ambience, right at the doorstep of downtown." ${ }^{20}$ As with most waterfront redevelopment projects, the main goals were to increase access and enjoyment of the water. Encompassing some sixty projects, Charles Centre gradually brought about the transformation of the waterfront with parks, plazas, office buildings, and leisure attractions.

On a smaller scale, the Promenade Samuel de Champlain in Québec City brings visitors to the waters of the Saint Lawrence River. “The project, that qualifies Champlain Boulevard from a highway into a landscaped, permeable urban boulevard, is a strong contribution to the restoration of the uniquely rich and diverse, albeit fragile coastal eco-system." ${ }_{21}$ Landscape architect Daoust Lestage's attention to scale reconnects users with the waterfront, while the use of local materials and vegetation anchors the site into its context.

\footnotetext{
${ }^{18}$ Announcement of 2009 ULI Awards for Excellence. Urban Land Institute, Atlanta, April 24, 2009.

${ }_{19}$ Duffy, Jim. 100 Years: Baltimore Gets a New Downtown. Baltimore Magazine. Nov 2007.

${ }^{20}$ Millspaugh, Martin L. The Inner Harbor Story. Urban Land Magazine. April 2003.

${ }^{21}$ Promenade Samuel-de Champlain. Canadian Architect. 1 May 2010.
} 
Perhaps most important in these types of urban renewal projects are inclusion of programs that stimulate the site and add an element of leisure. The Riverbank State Park in New York exemplifies this in its use of public programming atop a wastewater treatment plant. “In 1965, a Federal Court issued an order requiring New York City to treat all its remaining raw sewage before discharging it" 22 . This meant the city needed a new facility. As residents were quick to protest, a solution whereby the required infrastructure was made to benefit the public was devised. Despite numerous setbacks and public opposition, the project eventually got underway, but did not run smoothly. In 1987, complaints over smells led to the New York State Office of General Services (the construction agency responsible for much of the state's construction) taking over the construction of the park. ${ }^{23}$ All these efforts bore fruit. The "park" project, which included a skating rink, a multipurpose central building, an Olympic sized pool, a gymnasium and a large amount of outdoor parkland planted with mature trees (up to thirty feet high), all linked together with a continuous promenade, was completed in 1993. The first year following the opening attracted three million visitors. The project also meets "one of the great urban design ideals of managing to combine necessary industrial functions or urban waterfronts if not for shipping, for sewage - with the recreational waterfront both developers and activists have come to demand." ${ }^{24}$ This case study proves the possibility of using architecture to organize a transition from the city to the waterfront. The project shows that making infrastructure participatory - in this case, making a sewage treatment plant

\footnotetext{
${ }^{22}$ Dattner, Richard. Civil Architecture: The New Public Infrastructure. McGraw-Hill Inc. USA. 1 Jan 1995. p.42

${ }^{23}$ Ibid. p.50

${ }^{24}$ Gastil, W, Raymond. Beyond the Edge: New York's New Waterfront. Van Allen Institute. Princeton Architectural Press. New York. 2002. p.50
} 
also a park - can be truly successful. Such a project can help educate the public, while providing amenities and access to the waterfront.

The Zhongshan Shipyard Park in China, designed in 2002 by Turenscape, is located on the site of a former shipyard, and borrows its aesthetics from the industrial elements present on the site. Similarly to the Riverbank project, its goals were to provide recreational areas while providing an environmental benefit: remediating the existing landscape while also honouring the historical value of the site. "The rusting industrial elements from the shipyard were treated in various ways: some were preserved and restored, others were modified, and some were removed and new forms created in their place." ${ }^{25}$ The combination of existing industrial structures and new creations that complement the project is a strong design decision. The new additions also have pavilionlike qualities that invite activity and leisure, while alluding to the site's history.

In many cities in the post-industrial era, large polluted areas are being transformed into recreational parks, plazas and attractions. Cities are moving back towards their waterfronts, but now, the waters are places of leisure rather than work engines. Ottawa is unique in the fact that most of its urban waterfront remains fairly 'natural'. Though it was the heart of the timber trade in Canada in the $19^{\text {th }}$ century, many of the factories were located on the "Hull" (now Gatineau) side. Ottawa did not develop as an industrial port town. And finally, in the early 1960s, the National Capital Commission (NCC) expropriated

\footnotetext{
${ }^{25}$ Gaventa, Sarah. New Public Spaces. Mitchell Beazley. Octopus Publishing Group. Great Britain. 2006. p.152
} 
shoreline houses and forbade future shoreline construction. Much of the Ottawa River shoreline in the Capital therefore remains unscarred by industry. Today, a linear bicycle path follows the river's shoreline from the distant eastern suburbs to the distant western ones, as well as across the river and along the opposing shore. Introducing architectural events of small scale onto the Ottawa River shoreline would provide a way of reintroducing the river into the public realm. These could address the bicycle path. Their placement near the outfalls will serve to bring attention to the environmental issues associated with the city's sewer system. 


\section{Chapter 3 - Water Architectures}

"As the mediator between natural and constructed form, architecture can play a significant role in shaping our experience of water. Part of the fascination of water for architects is that its essential qualities - fluid, dynamic, transparentare unlike buildings in most respects, but both are essential for human life." 26

- Rene Davids, UC Berkley, Water \pm Architecture

Water can be a powerful and strong building material, its essential qualities being able to give transparency, energy and reflectance to architecture. Designing with and around water is a challenge that waterfront projects have to face with sensitivity.

Working in Venice, Carlo Scarpa was in a constant dialogue with water and his city's canals. Perhaps his background as a glassmaker gave him a fondness for the reflective and fluid properties that water can take advantage of in an architectural space. In his work at the Fondazione Querini Stampalia, Scarpa had an "understanding of water as an 'unsettling force' - as a medium caught between the solidity of the earth and the volatility of the sky." 27 The first floor of the building required renovations after a series of damaging floods. The natural elements he uses here are materials of composition. As the use of water in his "gardens is coupled with labyrinthine forms and rare stone materials," ${ }^{28}$ at the Stampalia, water flows over marble channels, seeming to "revive one of the most important symbolical associations in Buddhist gardens." ${ }^{29}$ The ambiguity between ground and water in the project is a recurring theme. The entrance footbridge is designed in such

\footnotetext{
${ }^{26}$ Water + Architecture. University of California, Berkeley.

${ }_{27}$ Williams, Robert. Presence \& Absence: Carlo Scarpa, Querini Stampalia, \& Water. 3SIXØ Architecture. 23 Jul 2009.

${ }^{28}$ Dal Co, Francesco. Carlo Scarpa: The Complete Works. Electa/Rizzoli. 2006. p.166

${ }^{29}$ Ibid p.167
} 
a way that you are brought lower than the ground line. As you enter the gallery, the ground plane sits somewhere below the water level, which "calls into question the solidity of the ground that is so precarious in Venice." ${ }^{30}$

The contrast in materials used with water is a popular theme also adopted by Canada's premiere landscape architect Cornelia Hahn Oberlander. ${ }^{31}$ Working together with architect Arthur Erikson on over three dozen projects, she repeatedly uses water as a reflective material in her gardens. ${ }^{32}$ The Anthropology Museum in British Columbia is a prime case of water being paired with architecture creating a total environment. It is a landscape that "integrates nature and structure while using water to reflect the landscape in simplistic ways." ${ }^{33}$ Though initially the pool was not filled due to concerns over seismic activity, it has recently been filled to fulfill her initial vision of the site.

The introduction of water elements in landscapes can be both infrastructural and aesthetic. The Bluffer's Park dunker system in Toronto is a wetland filtration system that cleans water from combined sewer outfalls through natural processes effectively. Built in the year 2000, it is the first of its kind in Canada. ${ }^{34}$ The system has become a feature in Bluffer's Park and an integral part of the area. It has also become a habitat for local wildlife. Not only has this system been proven to function very well, it has shown that constructed

\footnotetext{
${ }^{30}$ Williams, Robert. Presence \& Absence: Carlo Scarpa, Querini Stampalia, \& Water. 3SIXØ Architecture. 23 Jul 2009.

${ }^{31}$ Dümpelmann, Sonja, Beardsley, John B. Women, Modernity, and Landscape Architecture. Routledge. 11 Feb 2015.

${ }^{32}$ Aird, Louise. Dream Team: Architect Arthur Erickson \& Landscape Architect Cornelia Hahn Oberlander. June 1994.

${ }^{33}$ Ibid.

${ }^{34}$ Performance Assessment of a Flow Balancing and Wetland Treatment System - Toronto, Ontario. Sustainable

Technologies Evaluation Program. 2016.
} 
systems can become features along a shoreline. It proves that the point of contact between the city and the lake can become a mediation point. It is a visible infrastructural point in a public space. 


\section{Chapter 4 - The Typology of Small Outdoor Buildings}

"Small for our studio is a state of mind, not simply a scale we must graduate from on our way to the inevitable large" 35

- Carl Turner Architects, Small Thoughts and Projects

The London-based firm Carl Turner Architects works on a variety of projects, from residential, to commercial, to urban interventions. They tend to work on smaller-scale projects as this gives them more creative control over the final product. They are able to work with clients on the design and be a part of the construction process, which results in more personal projects that have real influence on their locations. The above quote expresses the firm's interest in the small scale, and that even large infrastructural projects are at some level "small" ones. This thesis is interested in small architecture as a strategy for scaling down the large and unknowable hydraulic infrastructure of Ottawa to something that a person can comprehend. Small architecture can become an orientation device, at the scale of the body, in a larger world.

The sixteen constructions presented in Chapter 6 are inspired by the buildings found in public parks. More than individual buildings on a site, they are parts of a larger system. They connect the network of trails along the natural river's edge and the system of water and sewers as they reach the water's edge. In Ottawa, most of the river's edge has remained "natural" or undeveloped. Even in the downtown core, the river's edge acts as a natural barrier to the built urban fabric, keeping the water's edge away from constructions.

\footnotetext{
${ }^{35}$ Carl Turner Architects. Small: thoughts and projects. Artifice books on Architecture. London. 2013. p.8.
} 
The NCC has for decades defended a position that is weary of building on the water, and the pavilions keep this mentality in mind. The "small" constructions, through their modest scale and location support the river's natural qualities. The sixteen buildings are more what hand-crafted is, in that they each respond to their site context and program in different ways and are designed to address the river differently. These are not merely a series of washrooms along the bike paths. Rather, they are each specific interventions along a set path that have their place in the procession from purification to treatment. They each address the issues of revealing the sewer outfall and alluding to the river's heritage in precise ways.

The issue of durability and access are important to their designs. Some of the pavilions are larger, such as the Ottawa Waterways Museum, and would not always be accessible, while others are more truly pavilions and would always remain open. The durability of materials is particularly important in these situations to simplify maintenance.

Unlike Bernard Tschumi's architectural follies at Parc de la Villette, which Tschumi had intended to remain un-programmed, the sixteen constructions serve specific pragmatic uses along the river. In the Parc de la Villette, Tschumi has designed the follies without any functional considerations. Their only role is to create a matrix that work to organise the park and act as reference points to visitors within the park. This thesis proposes that programmed architecture is necessary to fulfill the goal of acting as a mediator between the public realm and city infrastructure. 


\title{
Chapter 5 - Ottawa's Purified Water and Problematic Sewers
}

\begin{abstract}
"Where does that storm sewer opening from the river into the city's underneath go to, anyhow? I grab a headlamp and head in. It's long and low and dark and stinks and extends for miles. Underneath the city is another city. The one above begins to disappear." 36
\end{abstract}

- Ander Monson, Other Electricities

Exploring the sewers under Tucson, Arizona, Ander Monson becomes aware of the reality of the sewer. It isn't an enjoyable place, yet it stands as a necessary space for the healthy operation of the city. Even before the Gréber plan was conceived (1938 - 1950), the emptying of sewage into the Ottawa River had been a problem. As Gréber wrote in his proposal for the urban plan of Ottawa:

"The sewer system as existing are indicative of lack of foresight in their basic conceptions. On both the Ontario and Quebec shores of the Ottawa River, effluents of the sewer systems are the causes of water pollution. From the functional as well as from the point of view of hygiene, the systems are unsatisfactory. " ${ }^{37}$

Canada is known for its plentiful fresh water resources and high quality of drinking water, and Ottawa is no exception. In fact, it tests for more contaminants than any other Canadian city, and provides a highly rated quality of tap water to its population. ${ }^{38}$ The source of water for the entire city, excluding five small communities that use communal wells, is the Ottawa River. Two water purification plants (WPPs) at Britannia Bay, and Lemieux Island, produce roughly 290 million litres of drinking water each day for the city. ${ }^{39}$ The city uses twenty-two hundred kilometers of sanitary sewers, eighteen hundred

\footnotetext{
${ }^{36}$ Monson, Ander. Other Electricities: Stories. Sarabande Books. Michigan. 2005. p.102.

${ }^{37}$ Gréber, Jacques. Plan For The National Capital. 1950. p.100.

${ }^{38}$ Moore, Holly. Drinking Water in Canadian Cities Not Always Tested for All Contaminants. CBC News. 19 Jun 2015.

${ }^{39}$ City-Owned Wells and Purification Plants. City of Ottawa. 2015.
} 
kilometers of storm sewers, and two hundred and thirty kilometres of combined sewers. Seventy-six pumping stations help distribute this urban water throughout the city. ${ }^{40}$

Though the water quality is to be praised, Ottawans, like all Canadians, are one of the largest per capita users of fresh water in the world. ${ }^{41}$ With growing concerns over global issues such as peak water, these current trends need to be addressed. Ottawa has also had issues with the way it treats sewage. As with most urban areas developed prior to the 1940s, older parts of the city are serviced by a combined sewer system. This means storm water and wastewater is combined in the sewer before being sent to the wastewater treatment plant. Though for the dry season this does not pose a problem, when a large rainfall event occurs, this mixed wastewater overloads the sewage system and overflows into the Ottawa River. This dumping of waste into the river leads to harmful bacteria in the river and results in negative environmental and social impacts.

Although in Canada, data concerning these CSOs isn't typically collected, Ottawa has been exemplary in making such information accessible and transparent. Several projects are being worked on to solve these issues as part of the Ottawa River Action Plan (ORAP). The plan also includes projects that aim to retrofit certain areas of the city that have combined sewers. So far, the value of the work completed is estimated at $\$ 750$ million, but the problem of CSOs will remain largely unsolved through these projects. ${ }^{42}$ It

\footnotetext{
${ }^{40}$ Wastewater Services. City of Ottawa. 2015.

${ }^{41}$ Residential Water Use in Canada. Environment and Climate Change Canada. 17 Feb 2016.

${ }^{42}$ Combined Sewer Overflows (CSOs). City of Ottawa. 2015.
} 
won't be able to be completely resolved through renovations to the sewer system, and therefore, alternatives need to be considered.

In Ottawa, perhaps the most noticeable effect of sewage overflow is the closure of its beaches. When bacteria levels at public beaches are found to be unsafe for human exposure, local municipal health departments issue a "no swimming advisory." In Ontario, beaches must be closed when the standard of 100 colony forming units (cfu) of E. coli per $100 \mathrm{ml}$ of river water is exceeded. ${ }^{43}$ E. coli is a bacteria commonly found in human and animal intestines. Though it is usually harmless, it serves as an indicator for the presence of more harmful pathogens and diseases such as salmonella, shigella, noraviruses, enteroviruses, cryptosporidium, and giardia. ${ }^{44}$ E.coli presence in the Ottawa River can be caused by storm water runoffs, large bird populations such as flocks of Canadian geese, and/or combined sewer overflows. ${ }^{45}$ In 2011, beaches in Ottawa saw an average of 24 closure days out of 57 , meaning $41 \%$ of beach days were closed. 2006 was the worst recorded year for Ottawa. It was only discovered in 2008 that a gate valve in a sanitary sewer near Sussex Drive had been stuck open for several weeks, putting raw sewage directly into the Ottawa River. This led to Petrie Beach being closed for 45 days in 2006. ${ }^{46}$ Although the water quality in 2015 was noticeably better with an average of only 6.25 beach closure days, the water quality of the river remains an issue, and this, primarily due to CSOs. It is also projected that climate change will aggravate the effects of CSOs. Using rainfall projections linked to monitored CSOs in Southern Quebec, researchers

${ }^{43}$ Beach Closures. Ottawa Riverkeeper. 2015.

${ }_{44}$ E. coli. Public Health Agency of Canada. 20 Oct 2015.

${ }^{45}$ Beach Closures. Ottawa Riverkeeper. 2015.

${ }^{46}$ Water Quality Archives. Friends of Petrie Island. 7 Sep 2015. 
have estimated that CSO events will increase on a monthly basis by $4.2 \%$, potentially worsening the effect on Canada's waterways in the near future. ${ }^{47}$

${ }^{47}$ Fortier, Claudine and Mailhot, Alain. Climate Change Impact on Combined Sewer Overflows. 2014. 


\section{Chapter 6 -Architecture at the Outfalls}

In Ottawa, there are sixteen physical locations for the overflow of the waste and storm water blend into the Ottawa River called "outfalls." This thesis proposes to use the existing bicycle pathways along the river to connect purification to treatment through sixteen architectural pavilions. These pavilions at the outfalls, through materiality and form

will act as mediators between the river and the city, expressing the river's heritage through programmed, habitable spaces. They will become places that acknowledge the infrastructural issues of the city while providing services to its citizens relating to the site context of each outfall within the urban area.

The outfalls are spread out between the Lemieux Island Purification Plant and the Robert. O. Pickard Environmental Center, where the city's wastewater is sent to be treated, and returned to the river. Though hidden tunnels are a sensible infrastructural solution to the problem of combined sewers, they do not have a visual or informative impact to the city's population. The proposition develops sixteen pavilions at the outfalls, and adheres to the following principles based on the above: they expose their building systems and structures; they are unhidden and have a presence in the environment; they interact with and involve water; they are site specific; they are detail-oriented constructions; they address the bicycle path; and they are small. Areas surrounding the outfalls are also landscaped to reveal the systems underneath them, not literally by cutting or removing, but through landscaped materials. 
Though initially intended to become visible expressions of the city's hidden hydraulic network, and as such, to bring attention and bear witness to the infrastructural issues the city faces, the project's focus has somewhat shifted. As one imagines this proposal over a longer time span, and as the problem of sewage overflow is gradually reduced through engineering solutions, the constructions take on new meanings. As a set of sixteen discrete pavilions along the Ottawa River, each with its own contextual neighborhood associations, the constructions come to constitute a sort of civic monument that operates in two time frames, the past and the present. On one hand, the monument commemorates the outfalls' respective pasts, and on the other, it organizes and celebrates Ottawa's relationship to its northern river boundary, in the daily life of citizens. Each of the sixteen differentiated places of pause unfolds a nodal connection between the neighborhood it is sited closest to, and the shoreline proper. Though they are all connected on a marked pathway (the bicycle path), each is envisioned as an autonomous structure that directly relates, in form and function, to its context and location in the city of Ottawa. More simply, as programmed and useful spaces, the pavilions draw the population to the river's edge, and assert the mutual and reciprocal relationship between Ottawa and its water. 


\section{1 - Lemieux Public Washroom}

The first pavilion comprises a rest stop and a drinking fountain at the outfall looking over the Lemieux Purification Plant. With a view of the plant, users can drink from the tap, a direct line of pure drinking water from the plant. Openings in the structure invite users to see out towards the river. This view of the source of our drinking water materializes city infrastructure in a recognizable way. 


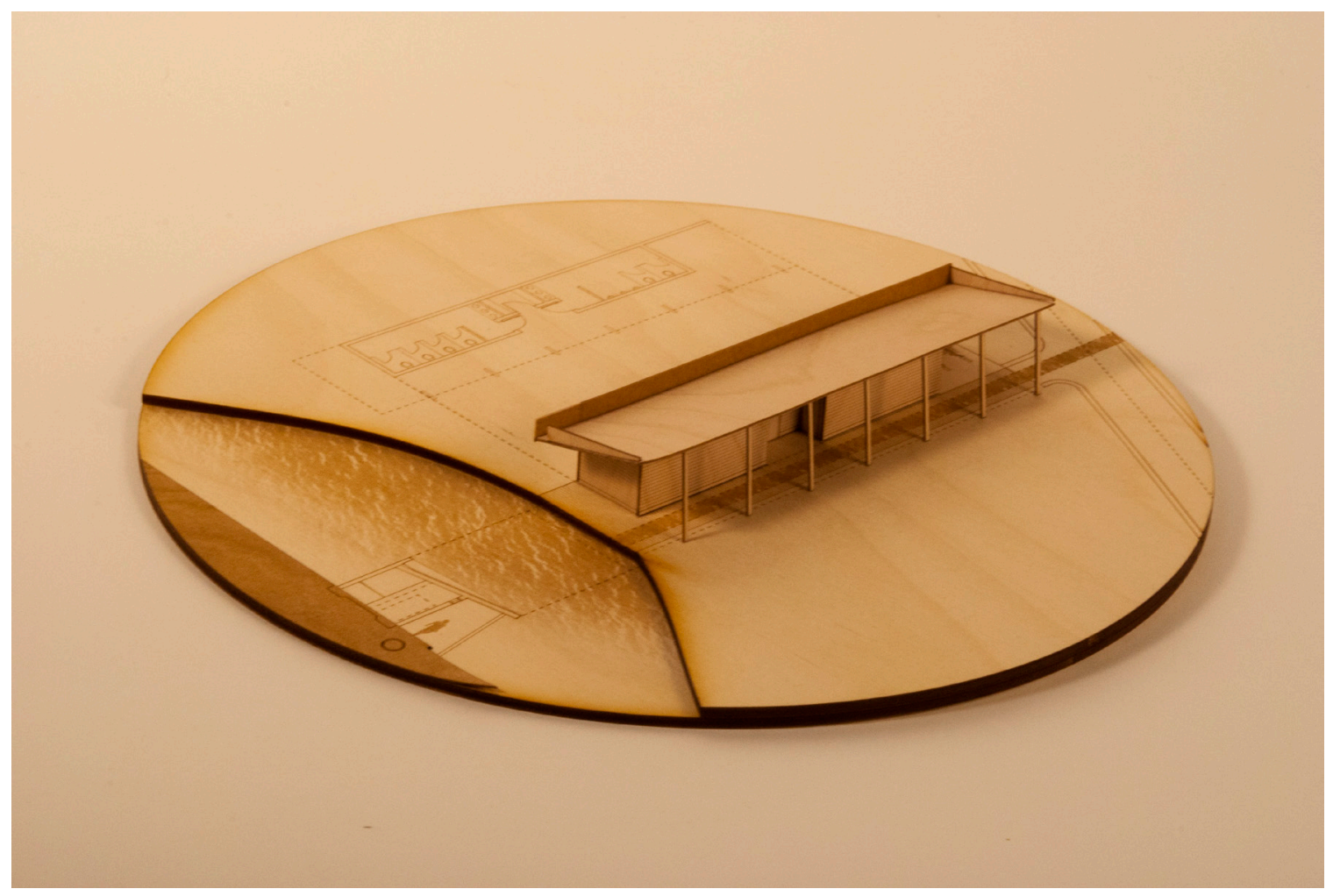

Figure 1 - Lemieux Public Washroom 


\section{2 - The Prince of Wales Tackle Shop}

The bridge is a connector between two shores. It has a pragmatic and infrastructural purpose. The second outfall is located just to the east of the Prince of Wales Bridge. The bridge is a multi-span Pratt truss bridge built in 1880. It served well into the 20th century but as other lines became more popular, it was abandoned and sold to the City of Ottawa in the early 2000 s. ${ }^{48}$ Though the future of the abandoned bridge is uncertain, it is currently used recreationally as an informal pedestrian crossing and there are plans to convert it to a multi-use pedestrian bridge. Users are also often seen rope swinging and fishing from the bridge. Though heavily used, it is closed off by fences that people have removed, and remains difficult to access. The pavilion is also a connection: a ramp smoothly leads from the pathway to the bridge, ameliorating a previously laborious passage. Visitors can use this new path to gain access to the bridge, which in turn connects them to the river, inviting a new viewpoint upon the water. A small tackle shop offers users the chance to purchase equipment for fishing.

\footnotetext{
${ }^{48}$ Churcher, Collin. 125th Anniversary of the Opening of the Prince of Wales Bridge. Bytown Railway Society. Branchline, Jan 2006.
} 


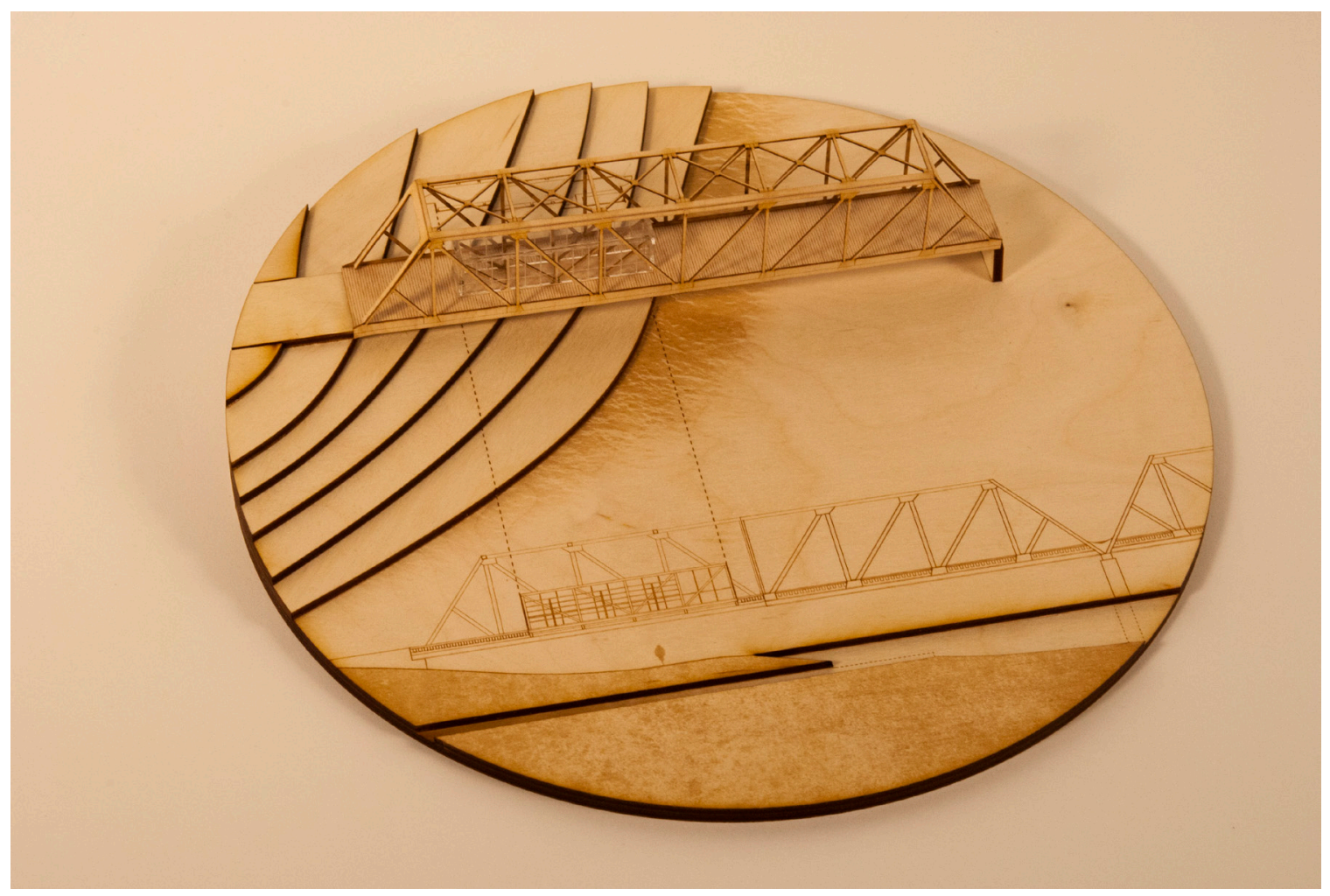

Figure 2-The Prince of Wales Tackle Shop 


\section{3 - Vigneau's Gallery (Artwork of the River by Local Artists)}

The hidden Nepean Bay, the location of the third outfall, acts as a microcosm for the Hudson's bay, a location Samuel de Champlain searched for on his trip across the Ottawa River in 1613. In his journey, he was told by a colleague, Vigneau, of the Hudson's Bay, but upon speaking to a native chief, was told it did not exist. This brought into question the loyalty of his colleague, and this uncertainty over his colleague's credibility haunted him for years afterwards. This pavilion, which houses a small gallery, plays with the ideas of credibility and trust. The visitor must trust the architecture to lead them in the right direction, not to misguide them. As a linear building that stretches into the river, this pavilion implies a strong water connection. At the termination of the building the views are to the east and west rather than north towards the river. The building deceives, alluding to Samuel de Champlain's frustrating journey. The building invites users to contemplate the artwork in a focused way. The view of the river is suppressed while one is inside. 


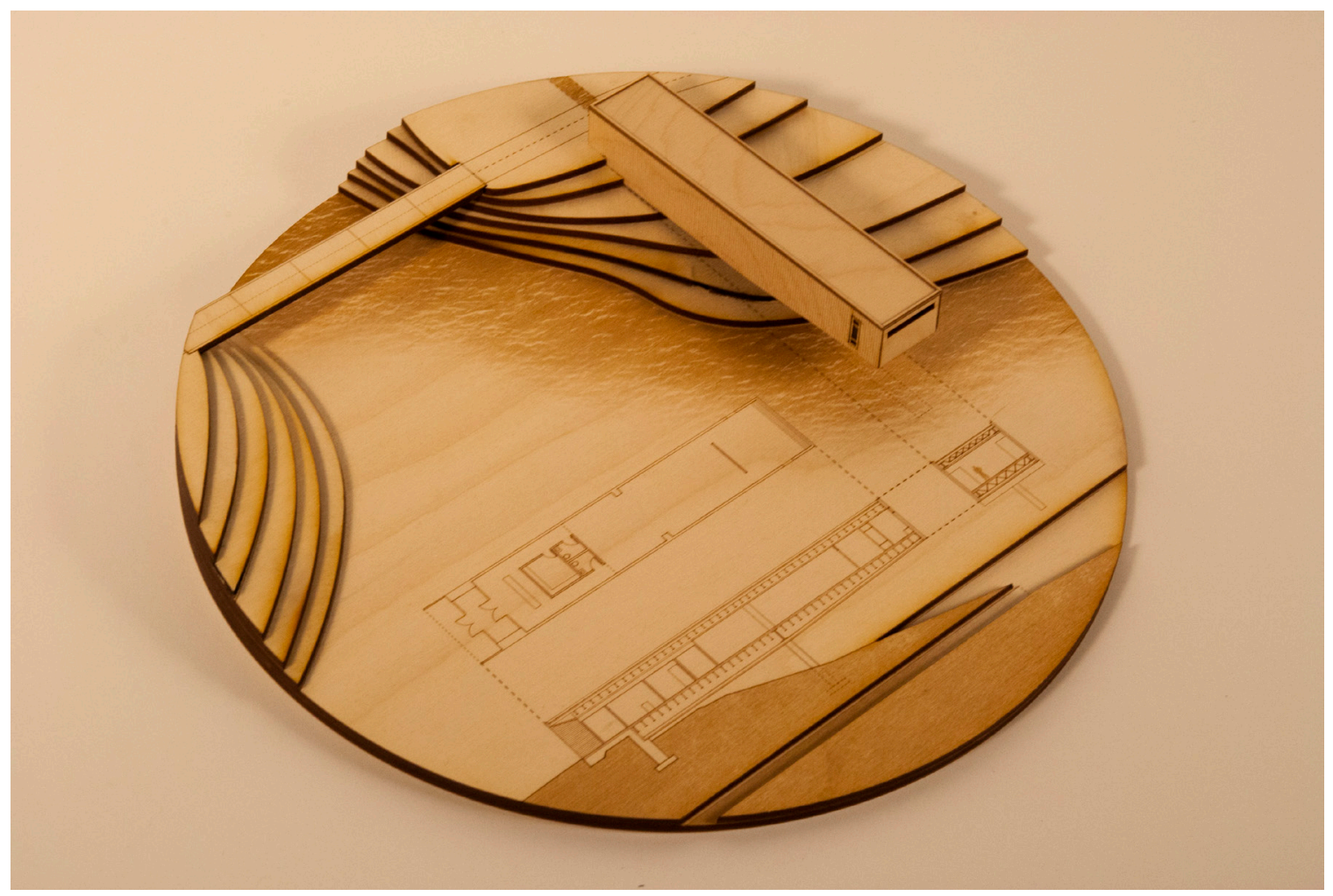

Figure 3 - Vigneau's Gallery (Artwork of the River by Local Artists) 


\section{4 - Whitewater Brewing Co. Bistro}

A fourth outfall is located at the historical Fleet Street Pumping Station, Ottawa's first pumping station. The latter is still used today to help send purified drinking water to the city. Opened in 1875 due to the threat of city fires, it is a designated heritage building designed by Thomas Keefer, a leading Canadian engineer in the field of water systems. ${ }^{49}$ It is also the only location that is setback from the river, and off the main trail. This idea of a deviation from the path marks it as unique and it therefore stands as a small bar, offering visitors a beer from a brewery that has roots in the Ottawa River. The small pavilion is located behind the historical limestone pump station, on top of an aqueduct, with no view to the river.

\footnotetext{
${ }^{49}$ Fleet Street Pumping Station (Ottawa), 1874-75. Ontario Heritage Trust. 2016.
} 


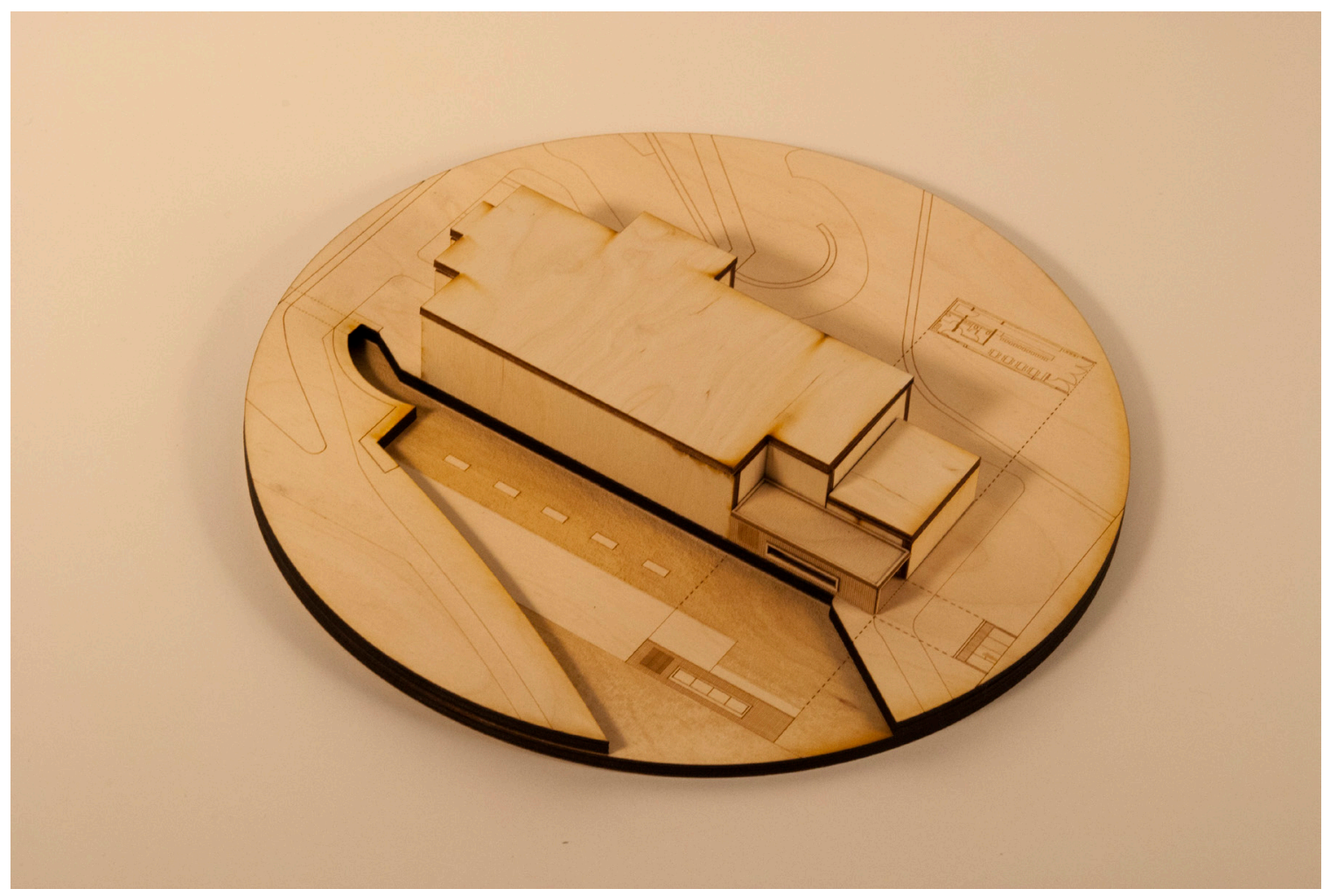

Figure 4 - Whitewater Brewing Co. Bistro 


\section{5 - Supreme Court Bridge}

The fifth outfall is located along the bike trails, just downhill from the Ernest Cormier building of the Supreme Court of Canada. The outfall is quite visible from the path, but is shadowed by the view of the river. The new bridge comprises a large wooden screen. It acts as a veil, concealing the view of the river, and making viewers turn their gaze inland, to the outfall located directly across from the bridge. 


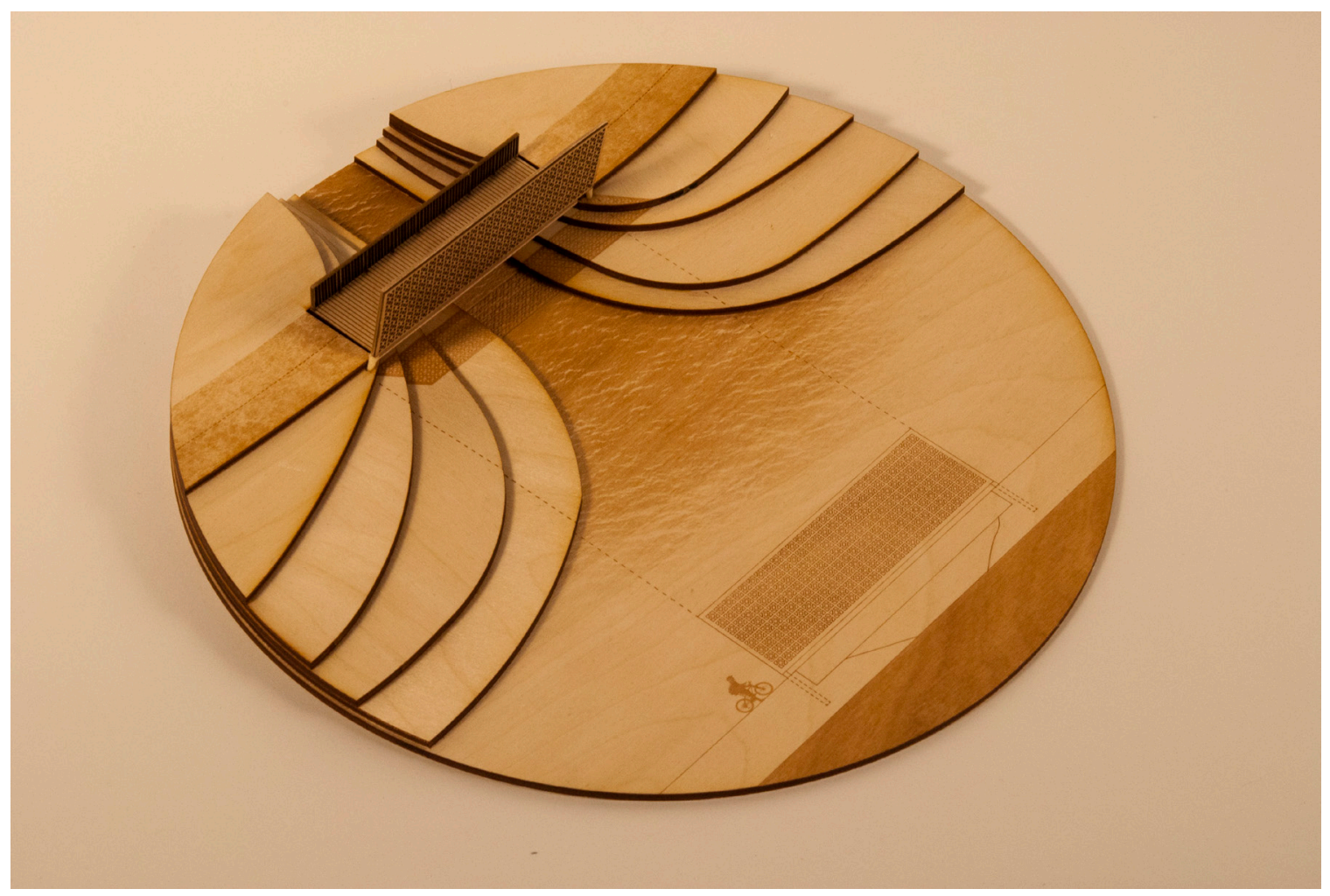

Figure 5 - Supreme Court Bridge 


\section{6 - The Ottawa Waterways Museum}

The location of the sixth outfall is an important one. It lies at the foot of the ravine behind Parliament Hill, at the entry of the national heritage site, the Rideau Canal. This proposed pavilion must be at the scale of the nation because it sits at a critical moment on the shoreline path, and is therefore frequented by locals and tourists alike. The architecture here is at a larger scale than the other buildings, and includes a small museum dedicated to the Ottawa River. The Ottawa River Museum educates visitors about the ecology of the local watershed, while explaining how the city-wide systems affect the river. It also acts as a midpoint in the pathway, a break from the journey where visitors can take notice of their position along the way. The building includes an educational center, a small gallery, offices for the Ottawa Riverkeeper Organization and a public washroom. It also incorporates the existing dock for boats awaiting the locks at the canal entrance. 


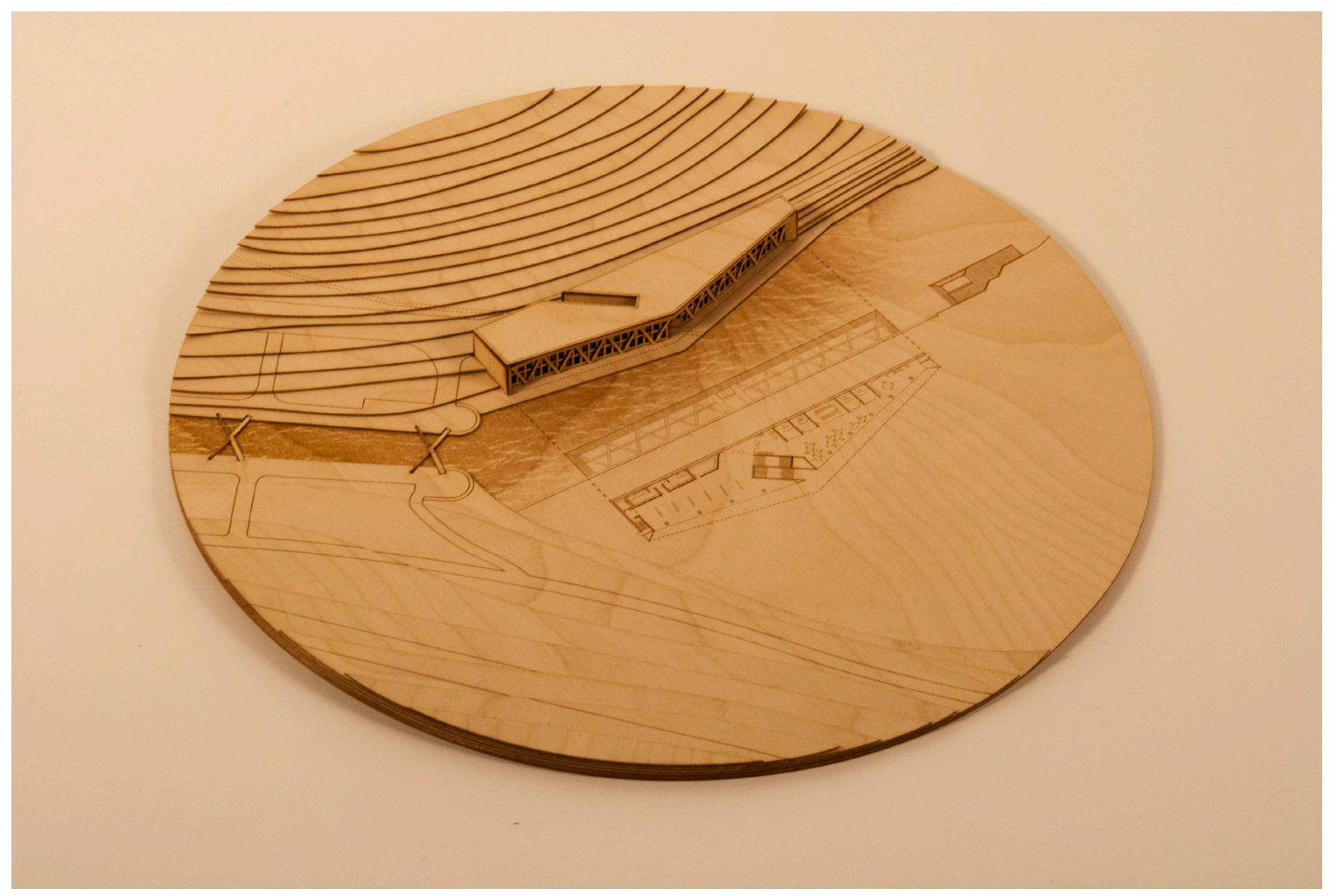

Figure 6 - The Ottawa Waterways Museum 


\section{7 - Monument for Loggers (The J.R. Booth Pavilion)}

Located just south of the Ottawa Rowing Club, the intervention here pays homage to the timber industry's loggers in the 1800s with a large hand crafted floating dock built in the way of the large-scale timber rafts that were floated down the river during the timber

trade boom in Ottawa. These rafts often included two thousand logs which loggers floated down the Ottawa River. The pavilion can also accommodate groups of 50 people for events and/or festivals. It features a cookhouse similar to those used on the rafts in the 1800s. 


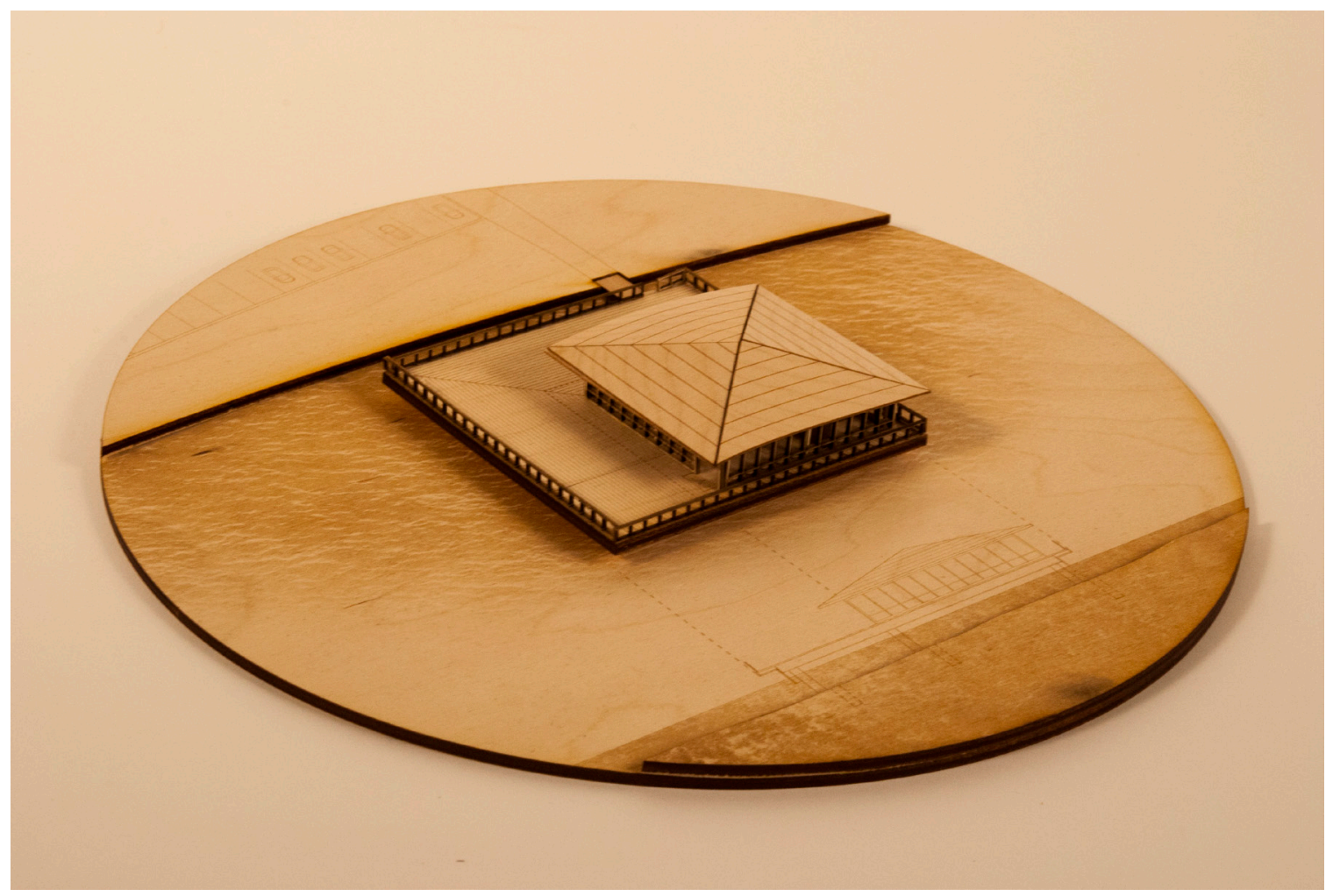

Figure 7 - Monument for Loggers (The J.R. Booth Pavilion) 


\section{8 - The Hockey Sweater (The Macdonald-Cartier Bilingual Library)}

The Macdonald-Cartier Bridge, named after John A. Macdonald and George-Étienne Cartier, joint premiers of the Province of Canada and founding fathers of Confederation, represents the link between French and English Canada. Here, the intervention includes a walkway, with inscriptions from the famous Canadian short story, The Hockey Sweater, an allegory of the tension between French and English Canada in the 1970s. A library featuring French and English books is incorporated at the end of the walkway acting as a gateway to the river. 


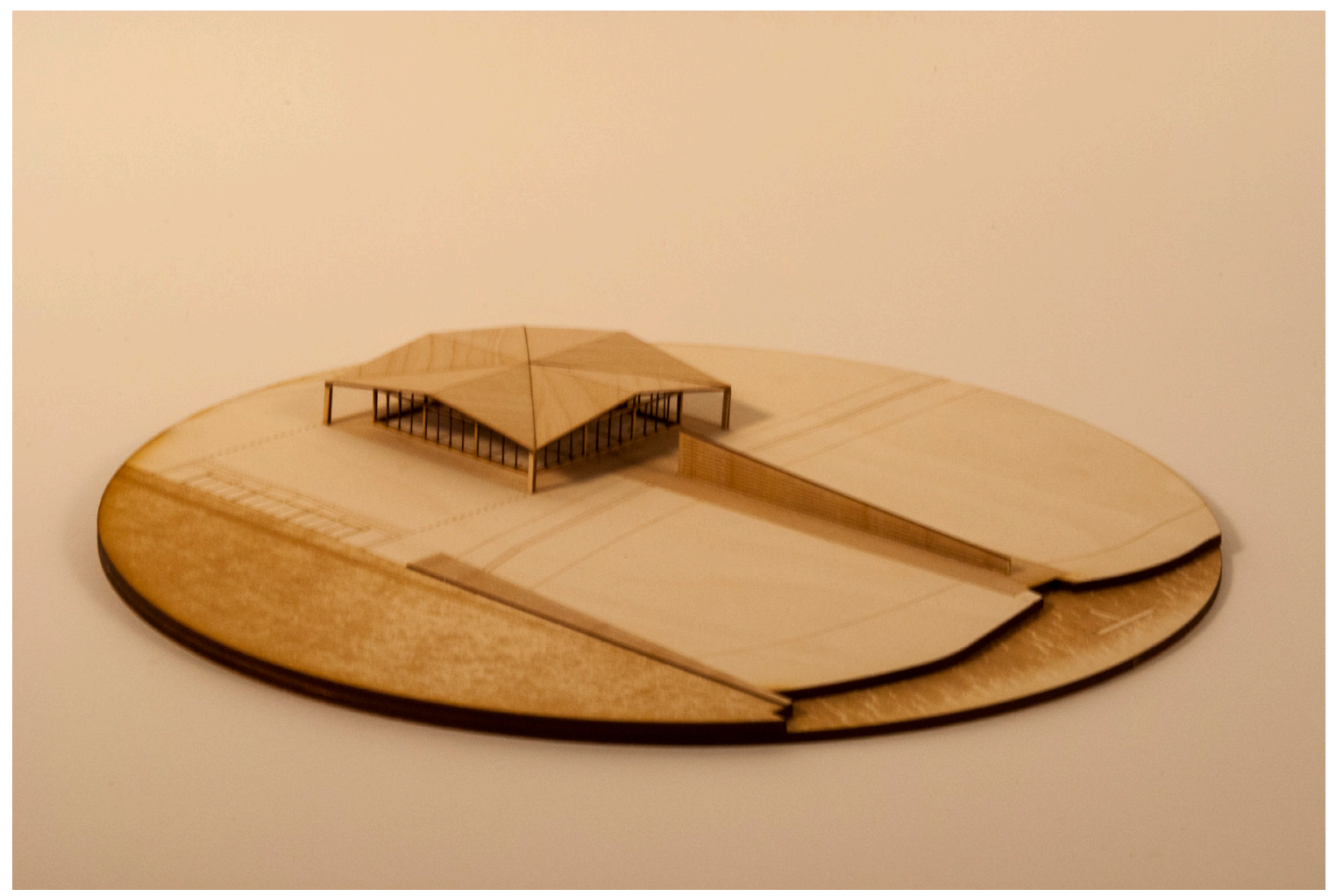

Figure 8 - The Hockey Sweater (The Macdonald-Cartier Bilingual Library) 


\section{9 - The Rideau Fountain}

The ninth outfall sits at the foot of the majestic Rideau Falls. The falls have been used for power generation since 1908 , producing approximately $8,542 \mathrm{MWh}$ of renewable energy per year. These falls are a symbol of the over 50 major dams and hydro-electric generating stations scattered throughout its tributaries and mainstem. A rest stop here includes a fountain, alluding to the Roman public baths at the extremities of its aqueducts. 


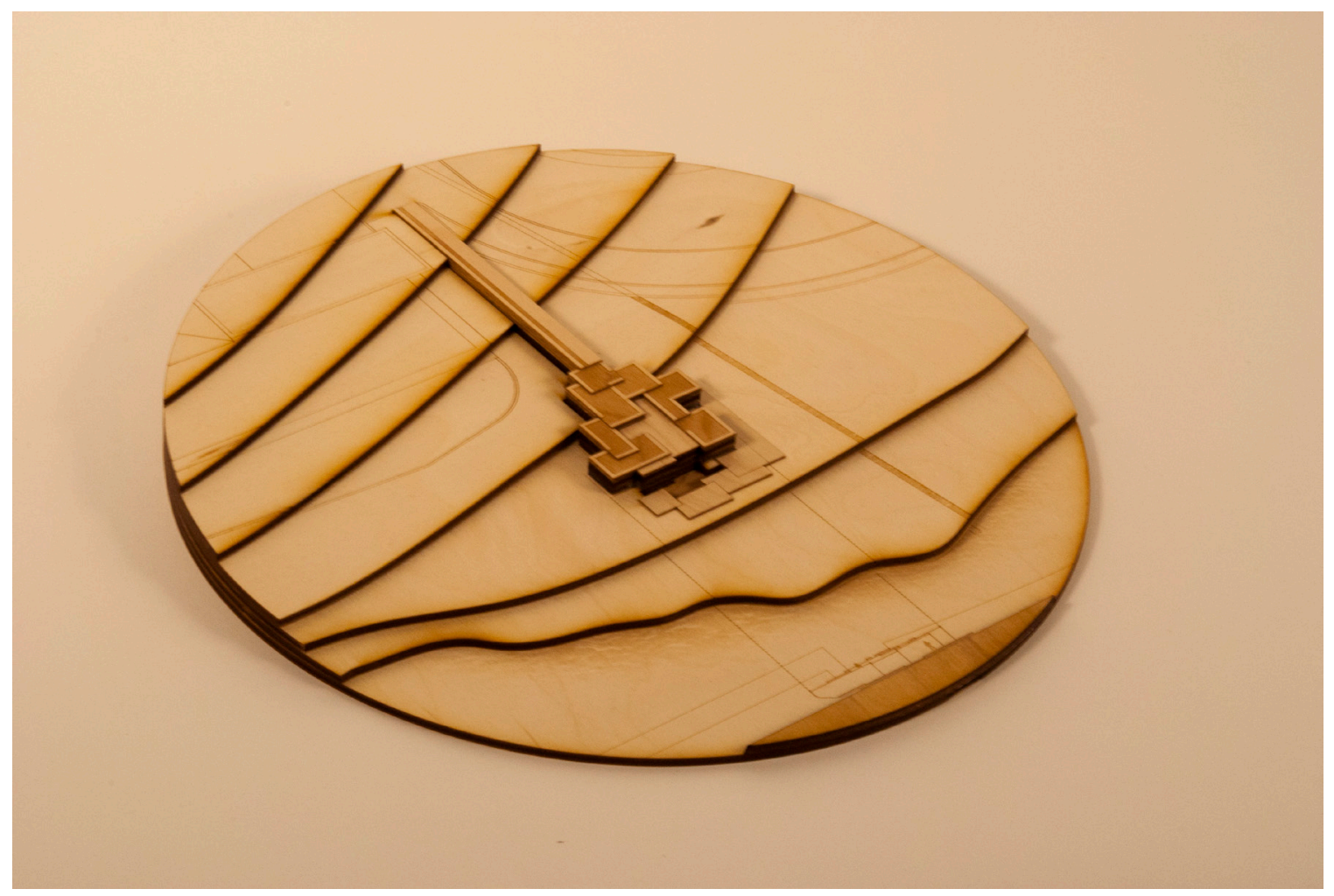

Figure 9 - The Rideau Fountain 


\section{0 - The Rural Well}

The tenth construction is a $14 \mathrm{~m}$ deep well that reaches down to expose the sewage lines.

Ottawa's rural communities use wells as their only source of water. As users descend into the well, they become aware of the underground system of sewage and drinking water lines under the city. It also offers a meditative and contemplative space along the path. 


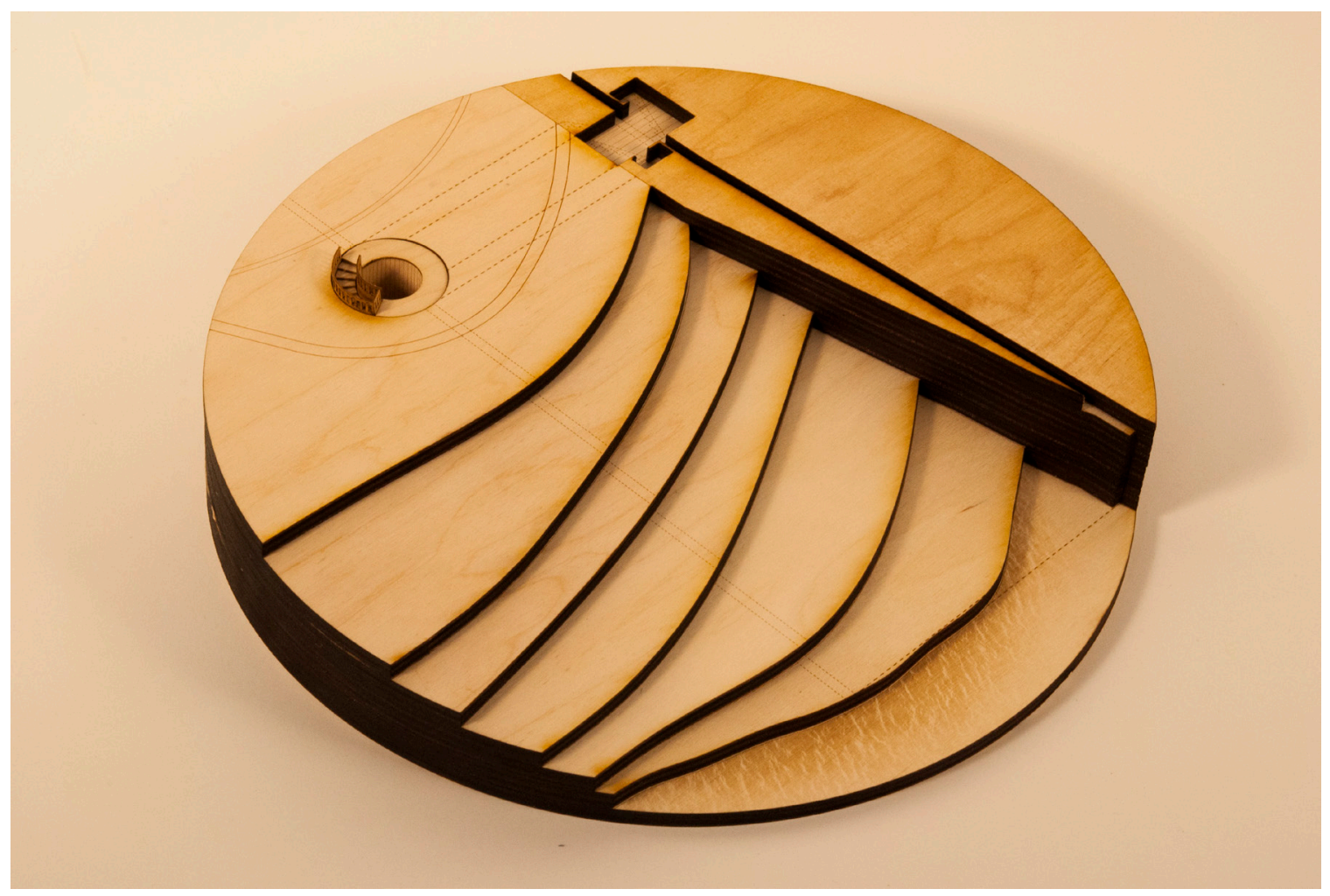

Figure 10 - The Rural Well 


\section{1 - The Rockcliffe Wedding Pavilion}

The existing gazebo at Rockcliffe Park is used for wedding ceremonies. The architectural intervention is to create a procession from the river to the gazebo, while creating supporting programs such as preparation rooms for the bride and groom. 


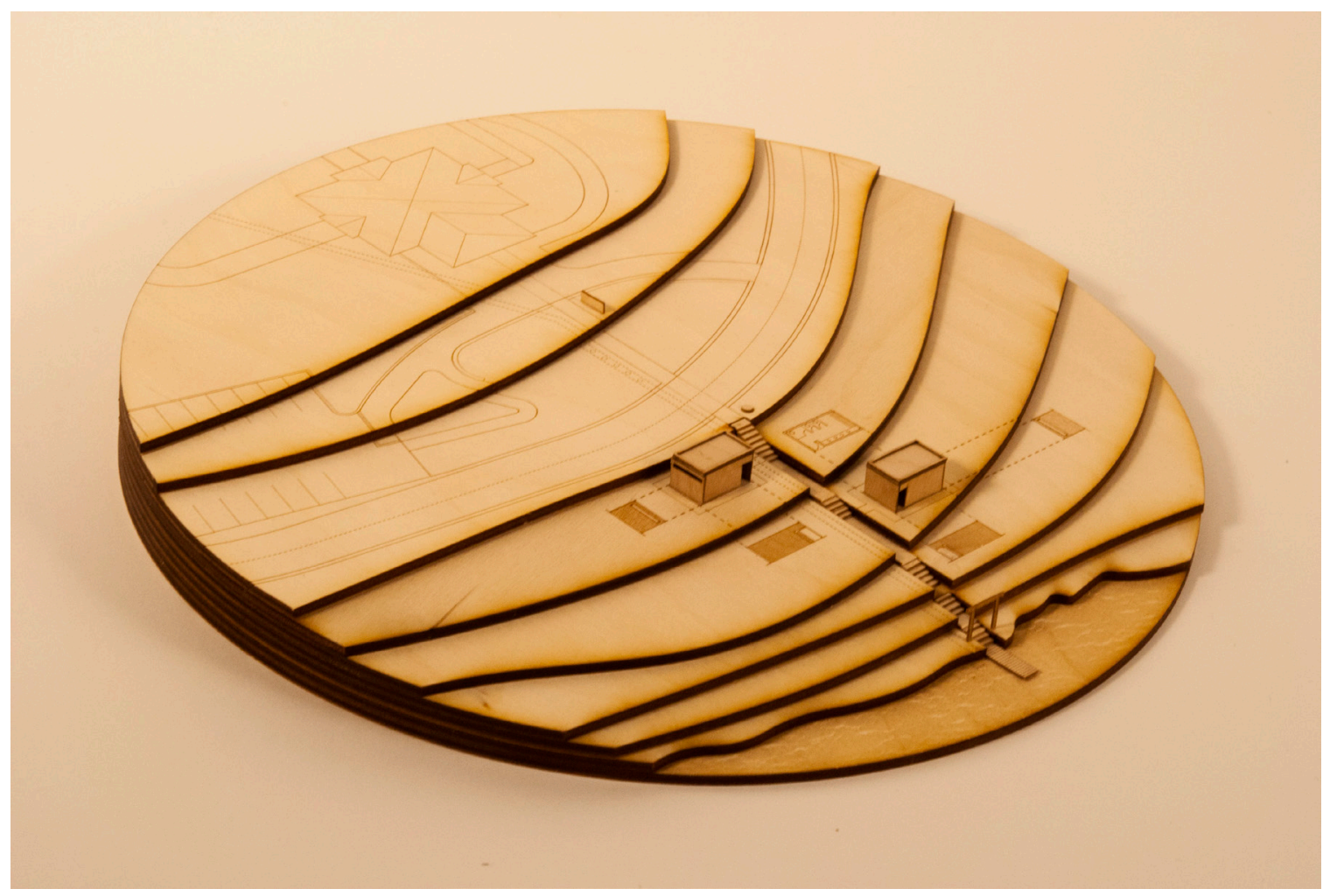

Figure 11 - The Rockcliffe Wedding Pavilion 


\section{2 - The New Edinburgh Boat Pavillion}

The New Edinburgh Club is a private boat clubhouse on the river. The river on the other hand, is the ultimate public realm. The pavilion here plays with the transition between private and public at the outfall. A new public boat launch and boat pavilion attempts to blur this line between public and private by balancing the access to the water. It also offers public storage of canoes and kayaks in the pavilion. 


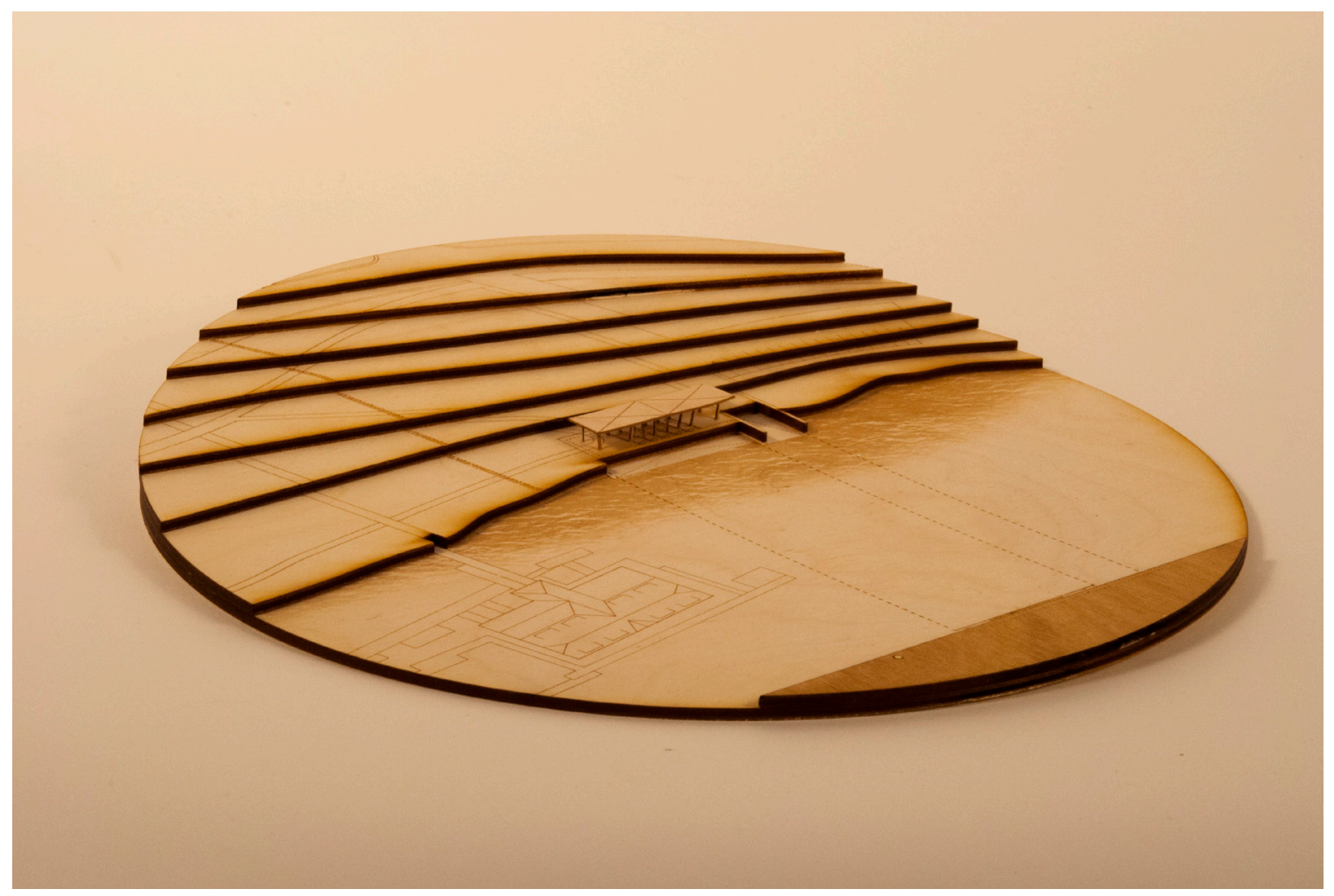

Figure 12 - The New Edinburgh Boat Launch 


\section{3 - The RCMP Stables (Horse Shelter and Trough)}

The thirteenth outfall is aligned with the Canadian Police College and horse training. The intervention includes a drinking trough for the horses that spans from the college to the river, and a shelter for them. This creates an opportunity for visitors to interact with the horses at the river, while producing a visual connection from the college to the river. 


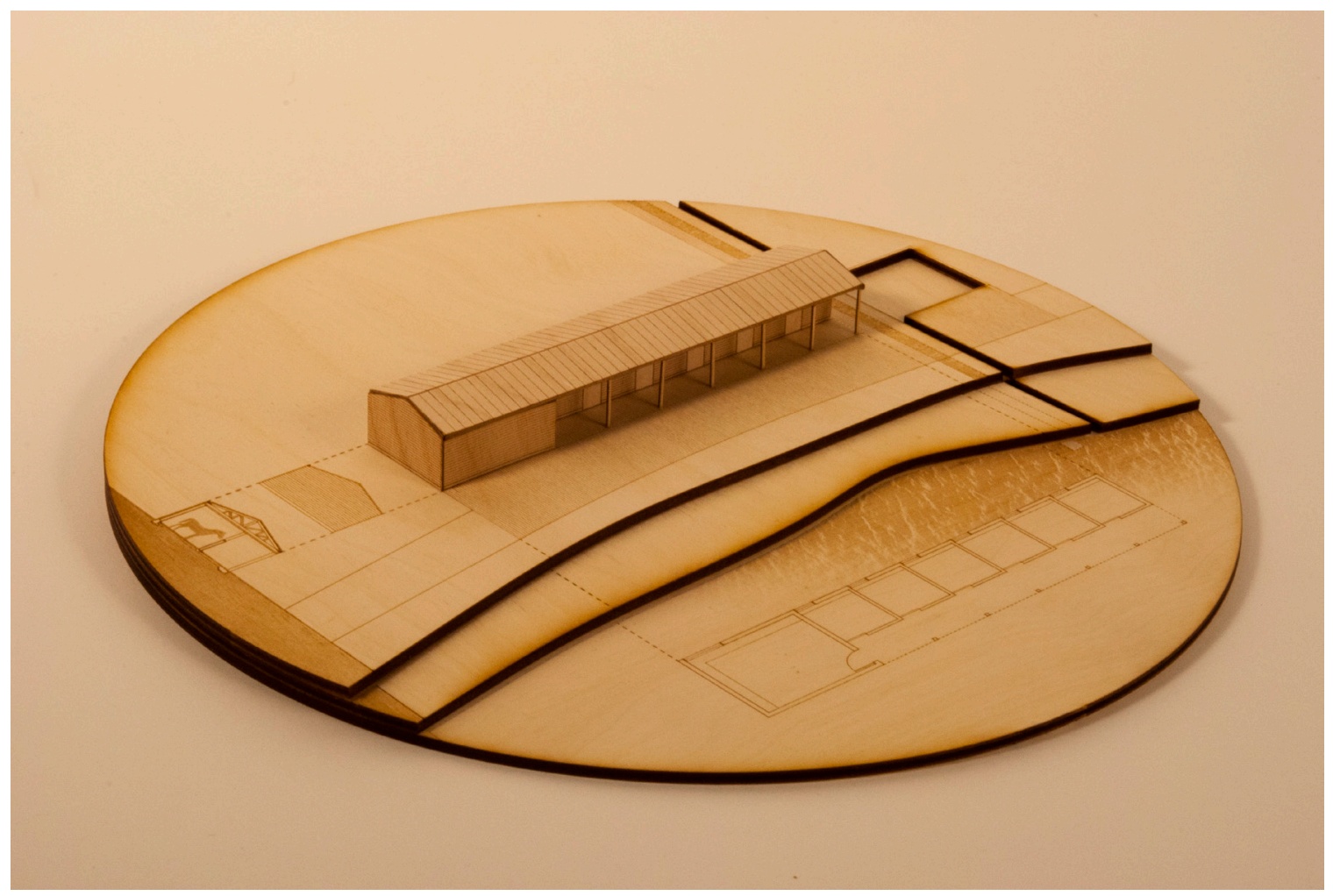

Figure 13 - The RCMP Stables (Horse Shelter and Trough) 


\section{4 - Canadian Aviation Museum Helipad}

Located at the Canadian Aviation Museum, this intervention at the fourteenth outfall looks up to the sky. It proposes a takeoff site for the museum's helicopter tours. The new helicopter pad offers visitors the prospect of viewing the river from a new perspective. The intervention here provides a waiting area and offices for museum staff 


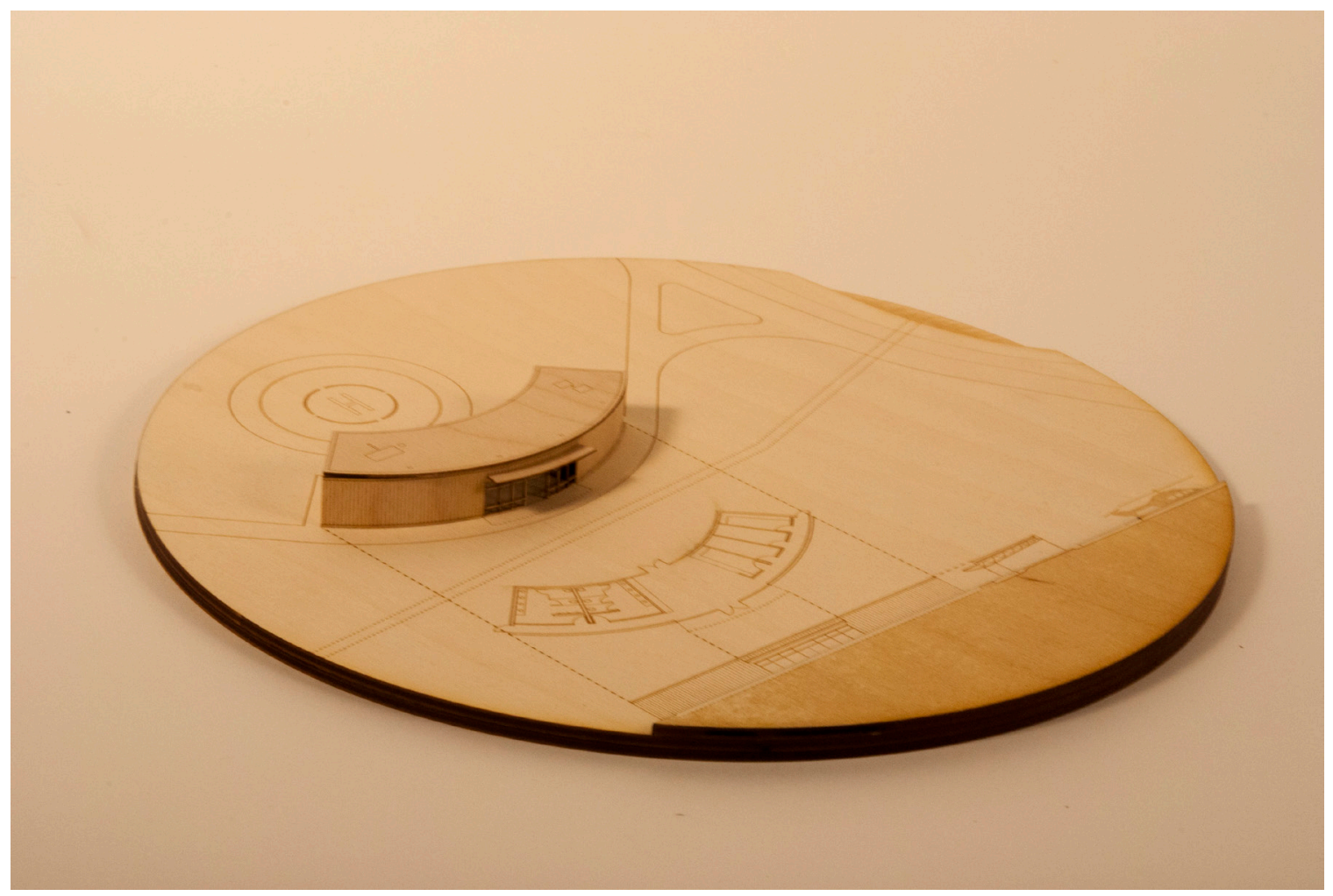

Figure 14 - Canadian Aviation Museum Helipad 


\section{5 - The Beacon Hill Rock Pool}

Though there are no significant sources of inspiration near the fifteenth outfall, this is the location that allows for the best natural access to the water. Stones along the shore are used for skipping, and feet are easily dipped in the water. The rock pool allows for experiencing the water further. The constructed reservoir is filled with the river's water, which at particularly bad times for overflows, may not be accessible. This intentional friction between the public amenity and the river acknowledges the city's waste management issues. 


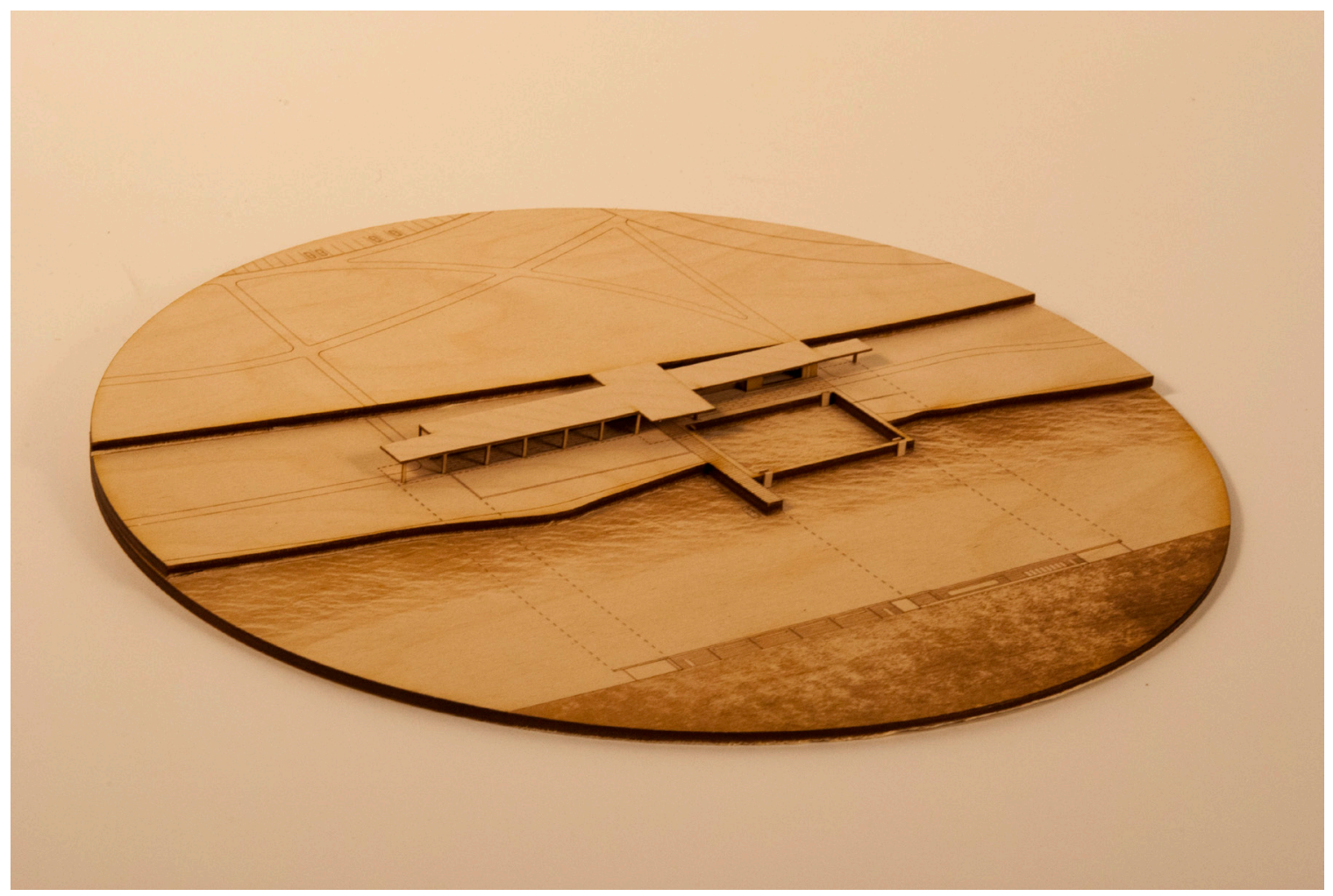

Figure 15 - The Beacon Hill Rock Pool 


\section{6 - The Ottawa River Wetlands}

The final stop is a symbol for the Robert O. Pickard Treatment center. It offers a potential solution in the form of a wetland treatment area for the overflow. The constructed wetland acts to filter the wastewater before returning it to the river. Inspired by Bluffer's Park in Toronto, it is the only 'natural' intervention, and poses a question as to a possible solution to overflows, while offering a new landscape along the river for visitors.

Walkways along the system's partitions allow for a different perspective towards the treatment of wastewater. 


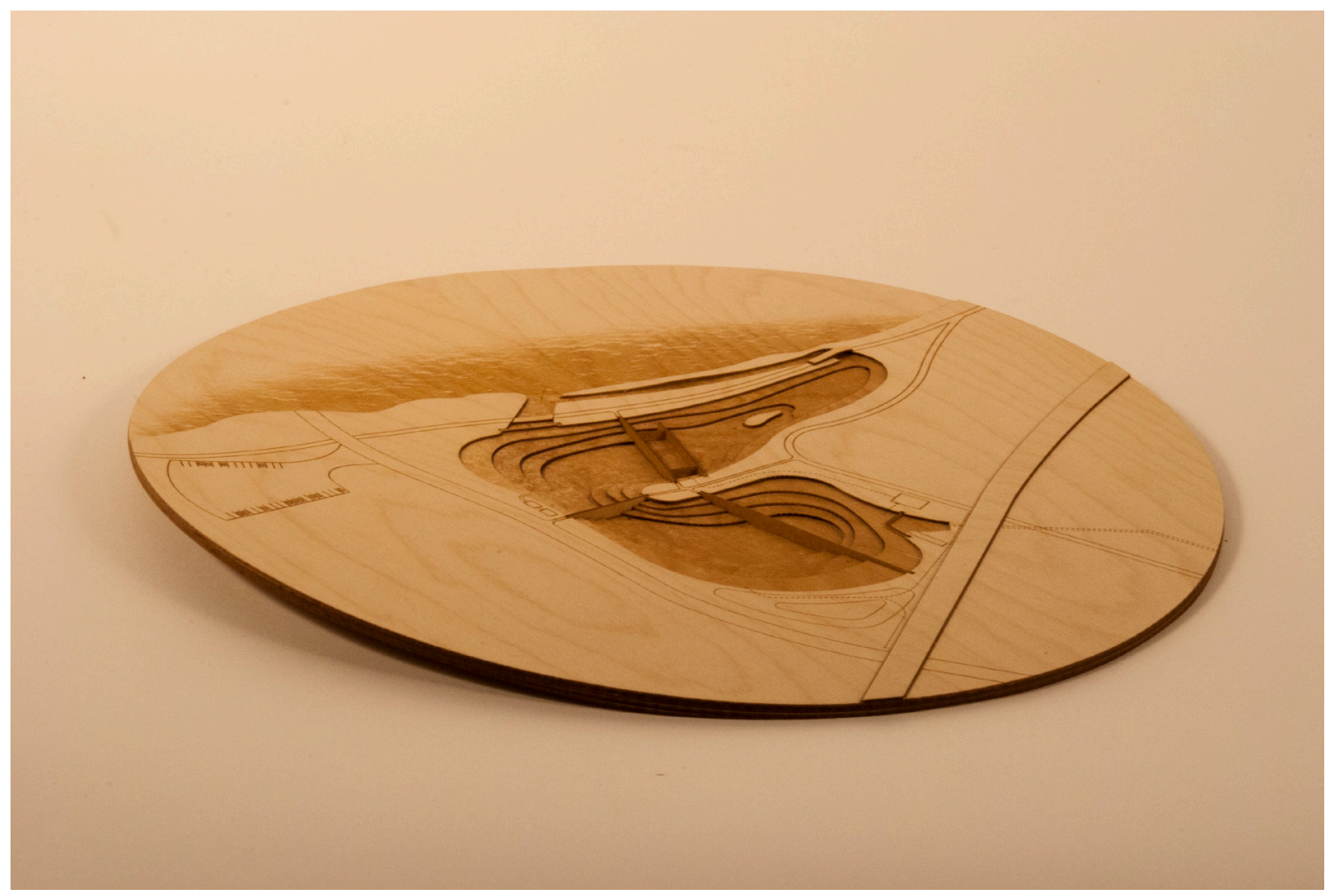

Figure 16 - The Ottawa River Wetlands 


\section{Conclusion}

Below the urban fabric of the city lies its invisible counterpart: a network of underground pipes, tunnels and storage tanks that serve to fulfill our basic needs. We remain disconnected from these infrastructures, unaware of their complex workings underneath us, yet we rely on them for our very survival. Citizens' disengagement with cities' engineering structures is a factor in a general carelessness towards our usage of this resource. Obliviousness is detrimental to the environmental resources we rely so deeply on. This is a particularly critical issue in the capital of Canada, in a country that identifies itself so strongly with the plentiful natural resources it harbours.

The sixteen constructions located at each sewage outfall attempt to reconnect citizens with their water source, while bringing awareness to the issues concerning Ottawa's combined sewer overflows. The damaging event of discharging our waste into the Ottawa River should be addressed in a public manner. Though solutions to the problem remain an engineering challenge, architecture can play a role in educating the public and mediating between the engineered infrastructure and the river as a public space.

As cities' waterfronts have moved from industrial shores to increasingly public territories, citizens are rediscovering their rivers as dynamic communal arteries. The thesis seeks to also speak about the heritage of the Ottawa River. From Algonquin land, to a key factor in the Canadian timber trade, the Ottawa River has been a driving factor in the 
development of Ottawa as a capital. Architecture at the Outfalls strives to give an architecture to this history.

The small scale buildings along the existing bicycle paths act as intermediary nodal points which bring activity to the river. The necklace of sixteen constructions guides the public to the shoreline in an intimate and tactile manner, while bringing attention to the infrastructural systems they use. The project introduces programmatic elements, bringing infrastructure and the river closer to everyday activities. Through the mediation of the sixteen constructions, the Ottawa River becomes a visible, topographical, and spatial element in urban and suburban life in the Canadian capital. Architecture at the Outfalls brings the discrepancies of Ottawa's hydraulic system to the surface. By intersecting them with a popular leisure path, the project opens up a space of increased awareness in a place Ottawa citizens are likely to find. 


\section{Appendices}
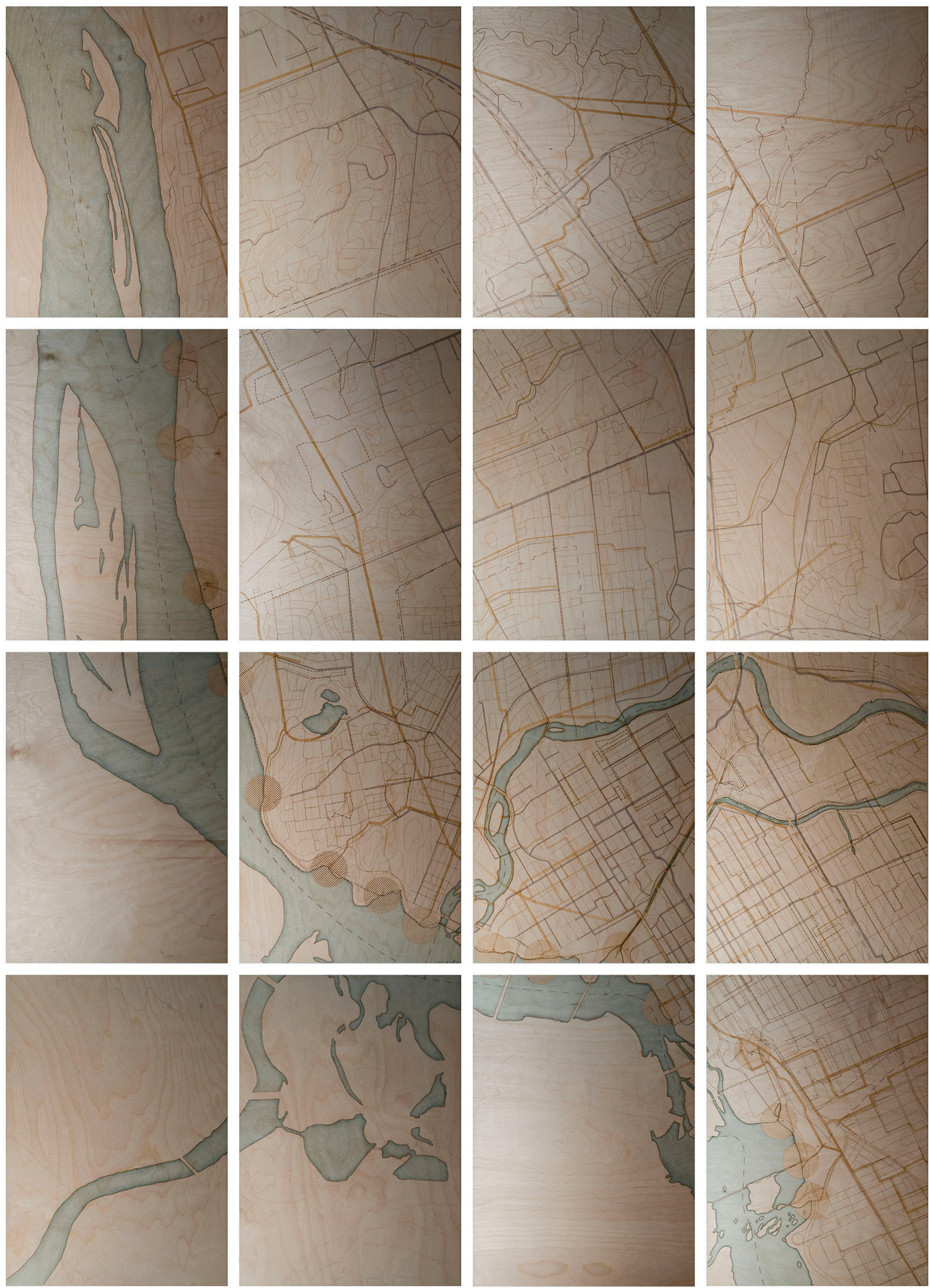

Appendix 1 - Sixteen map panels showing the location of the sixteen outfalls 


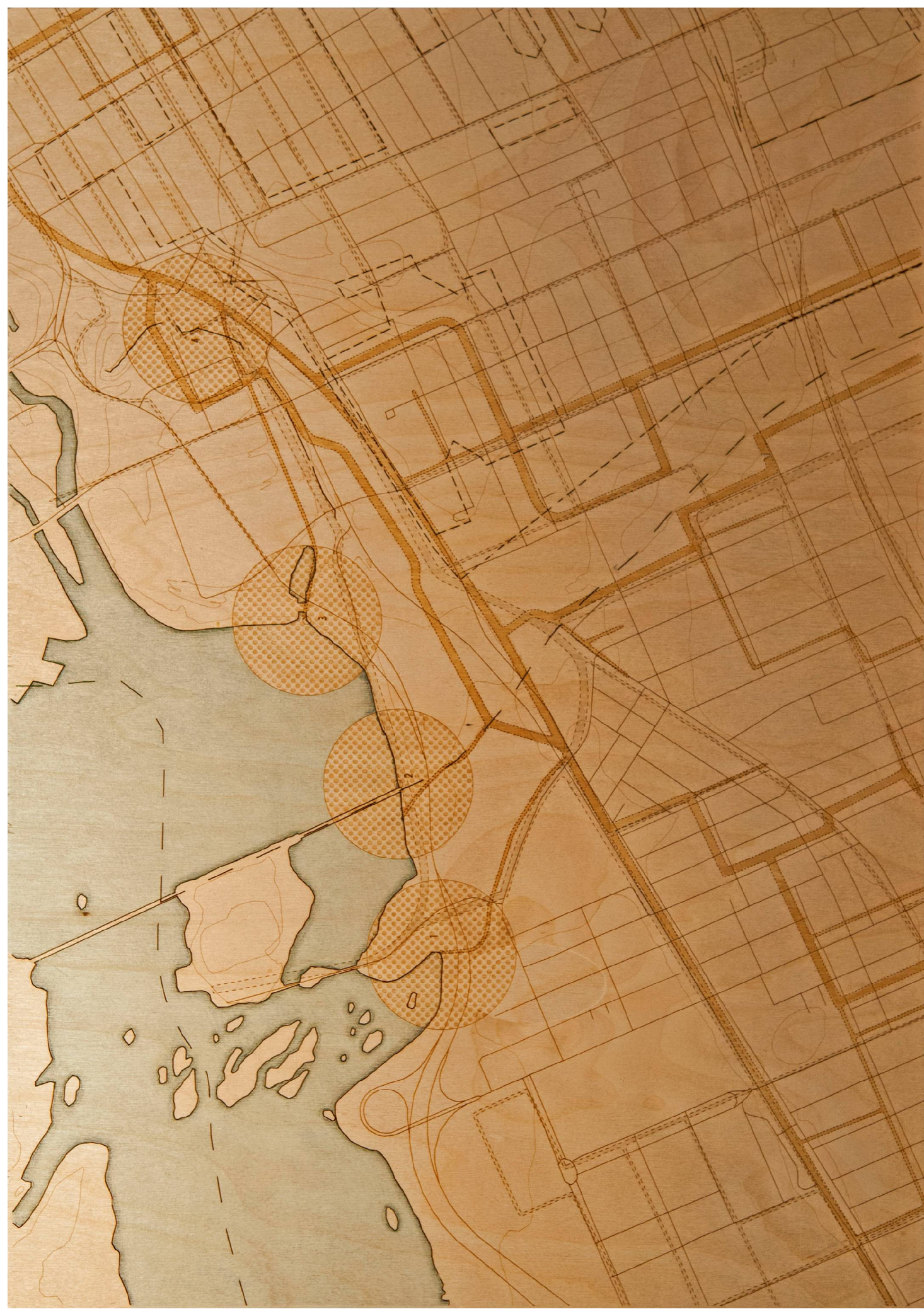

Appendix 2 - Single map panel with lasercut lines. 


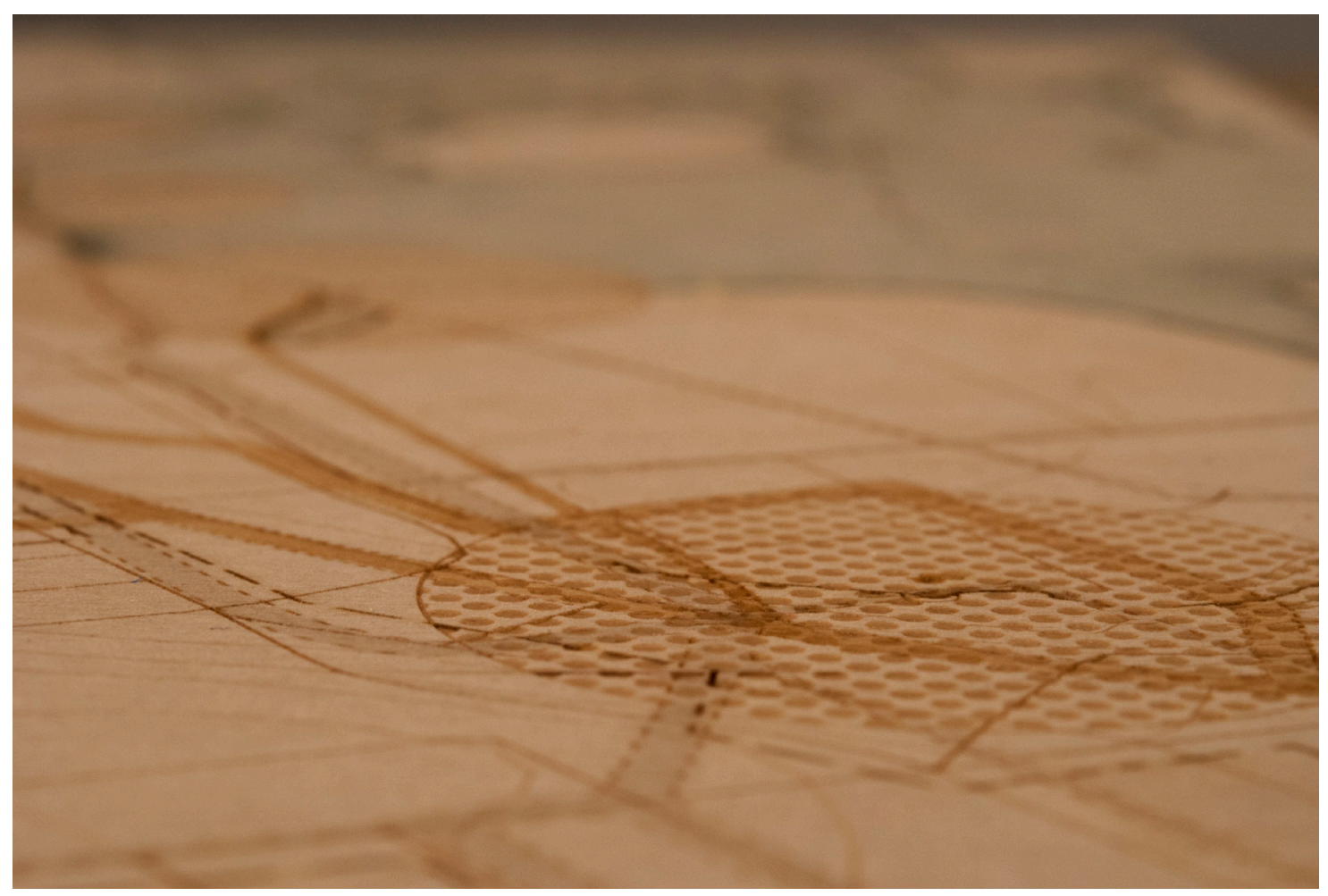

Appendix 3 - Detail of lasercut map panel.

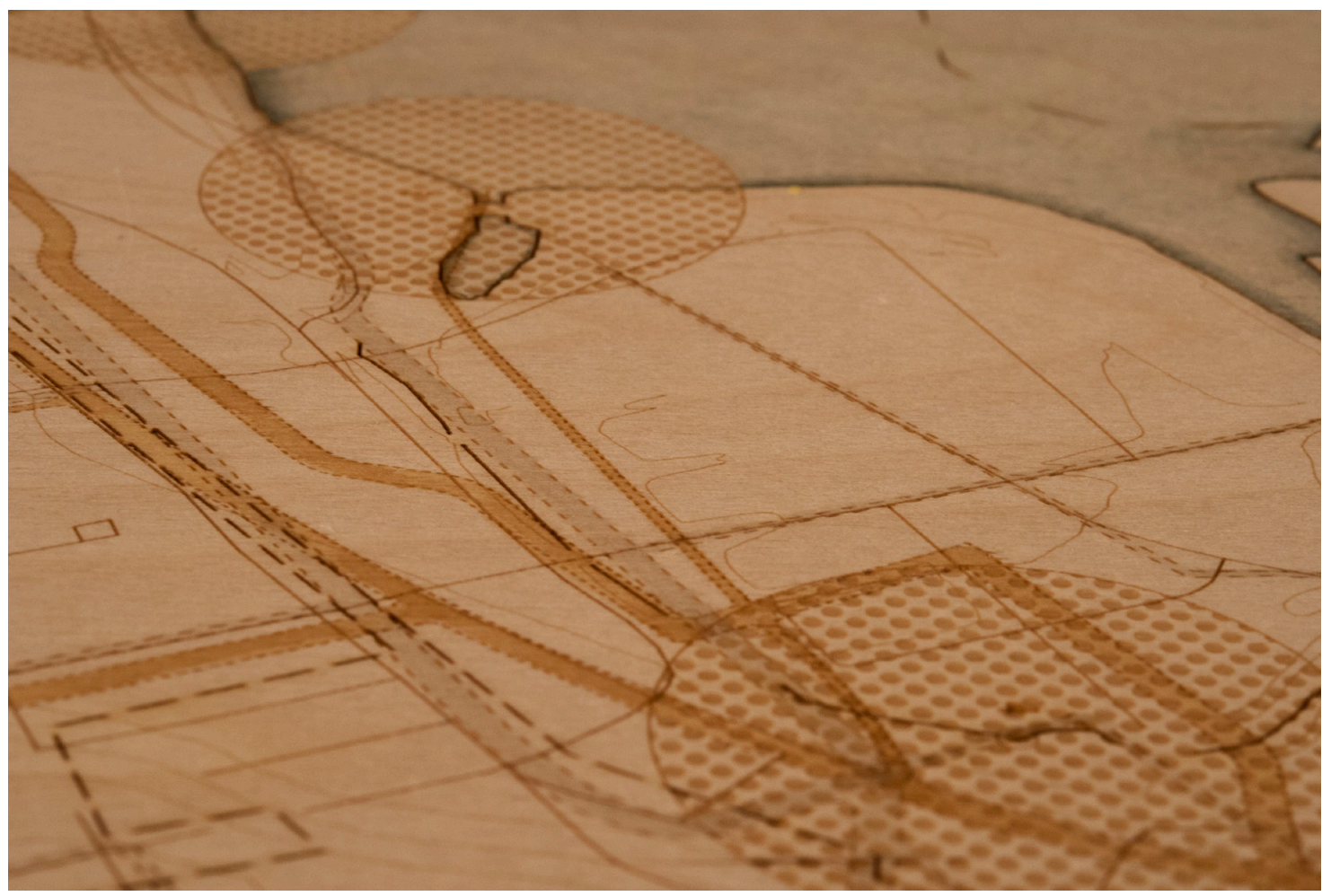

Appendix 4 - Detail of lasercut map panel. 


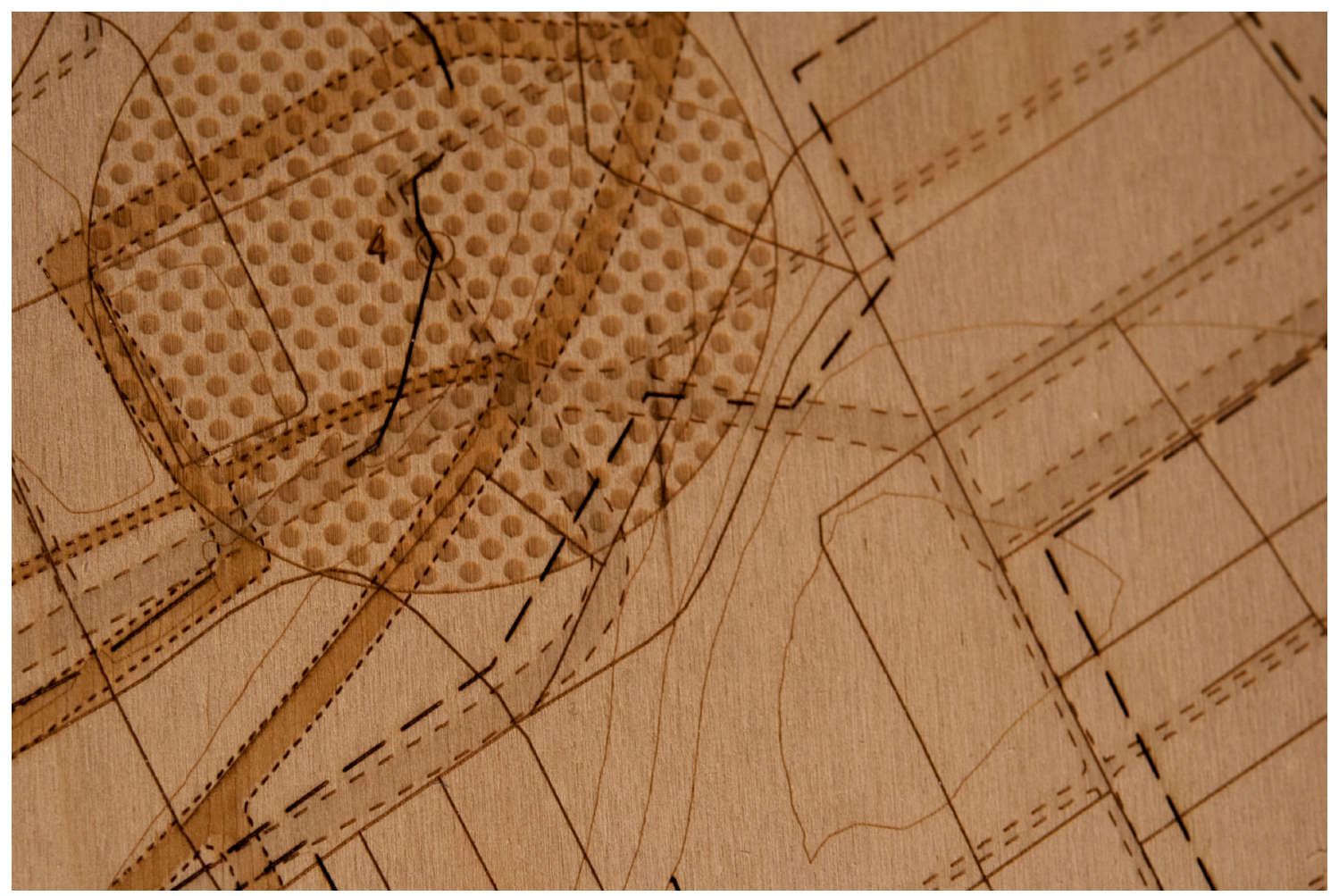

Appendix 5 - Detail of lasercut map panel.

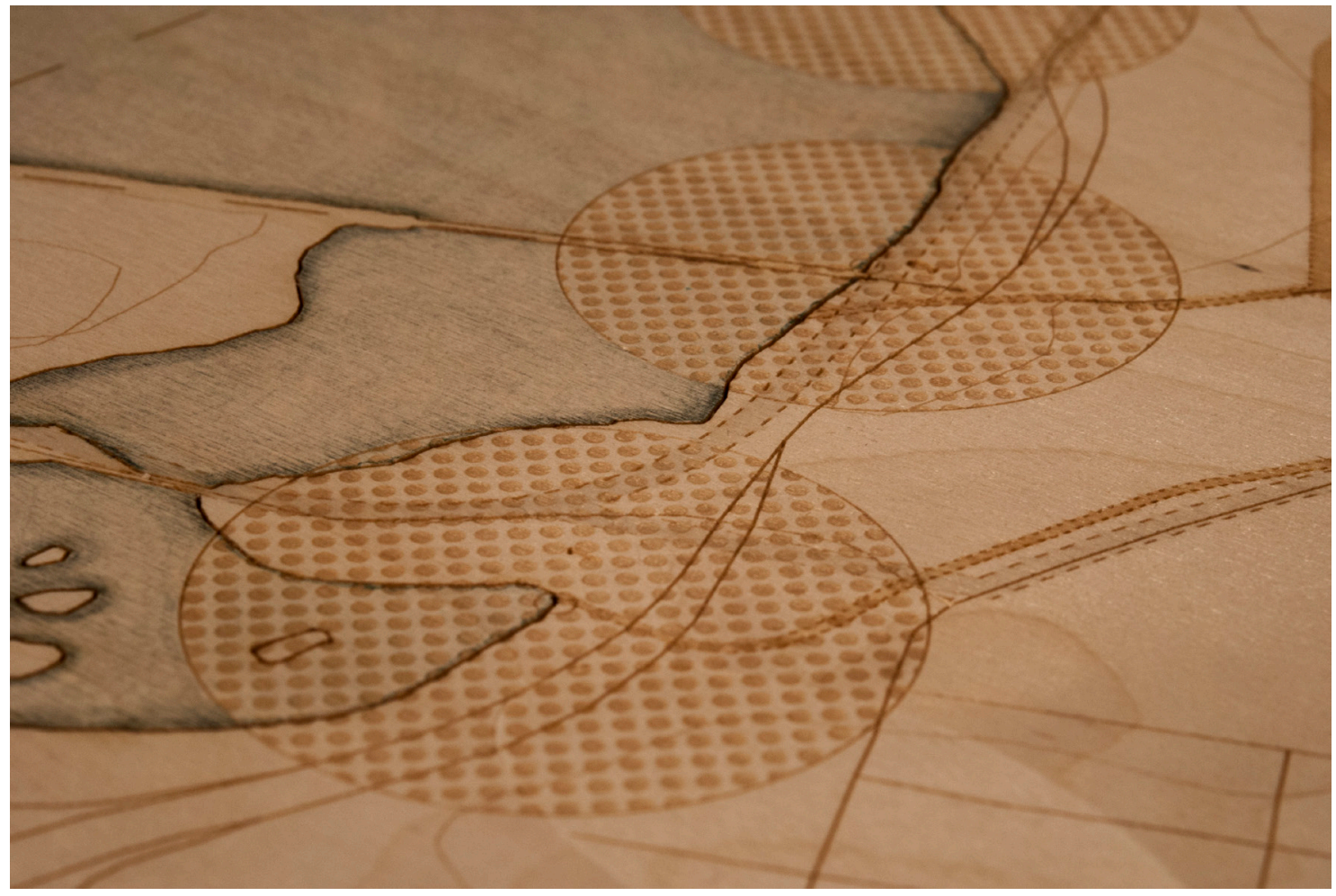

Appendix 6 - Detail of lasercut map panel. 

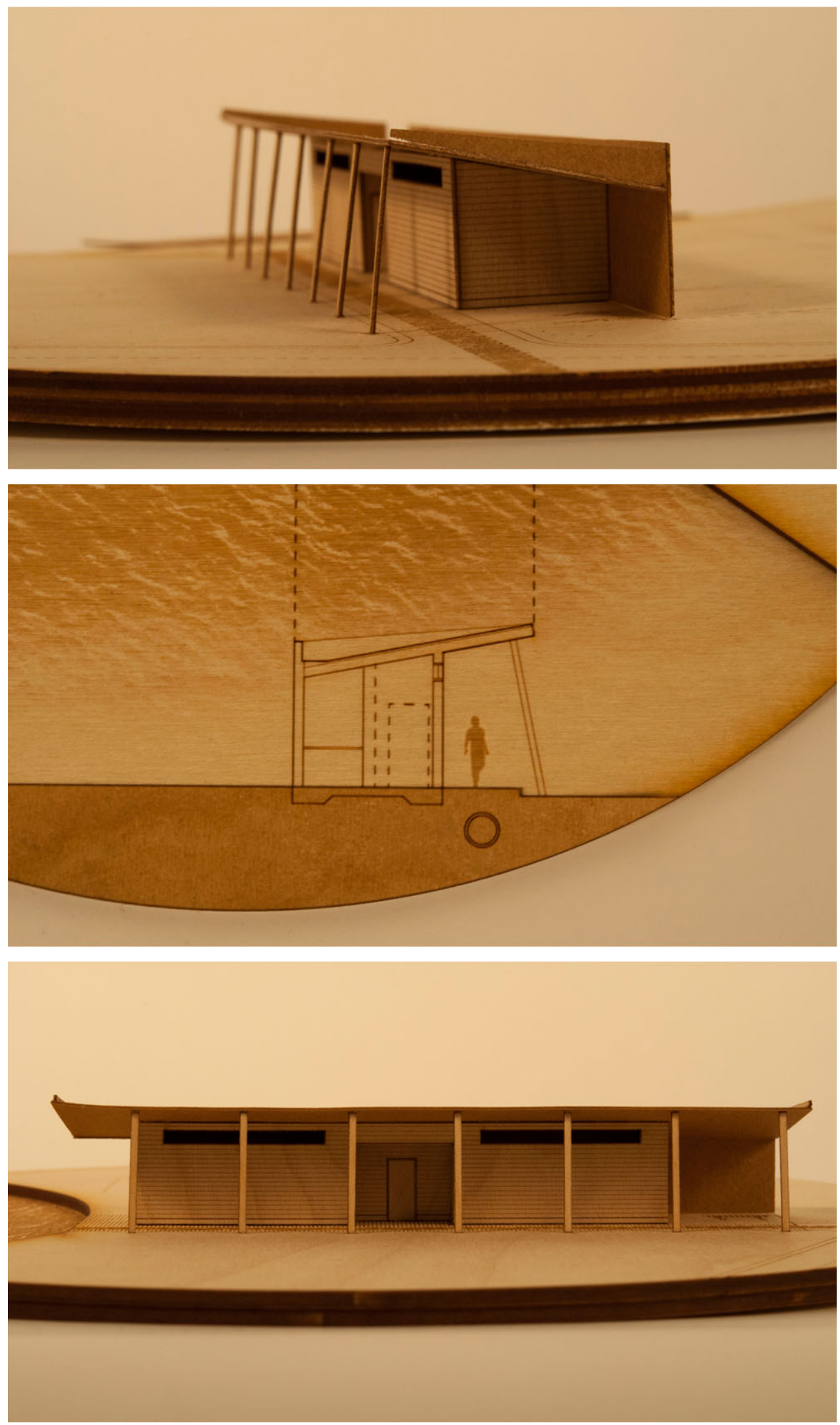

Appendix 7 - Construction 1 Model 

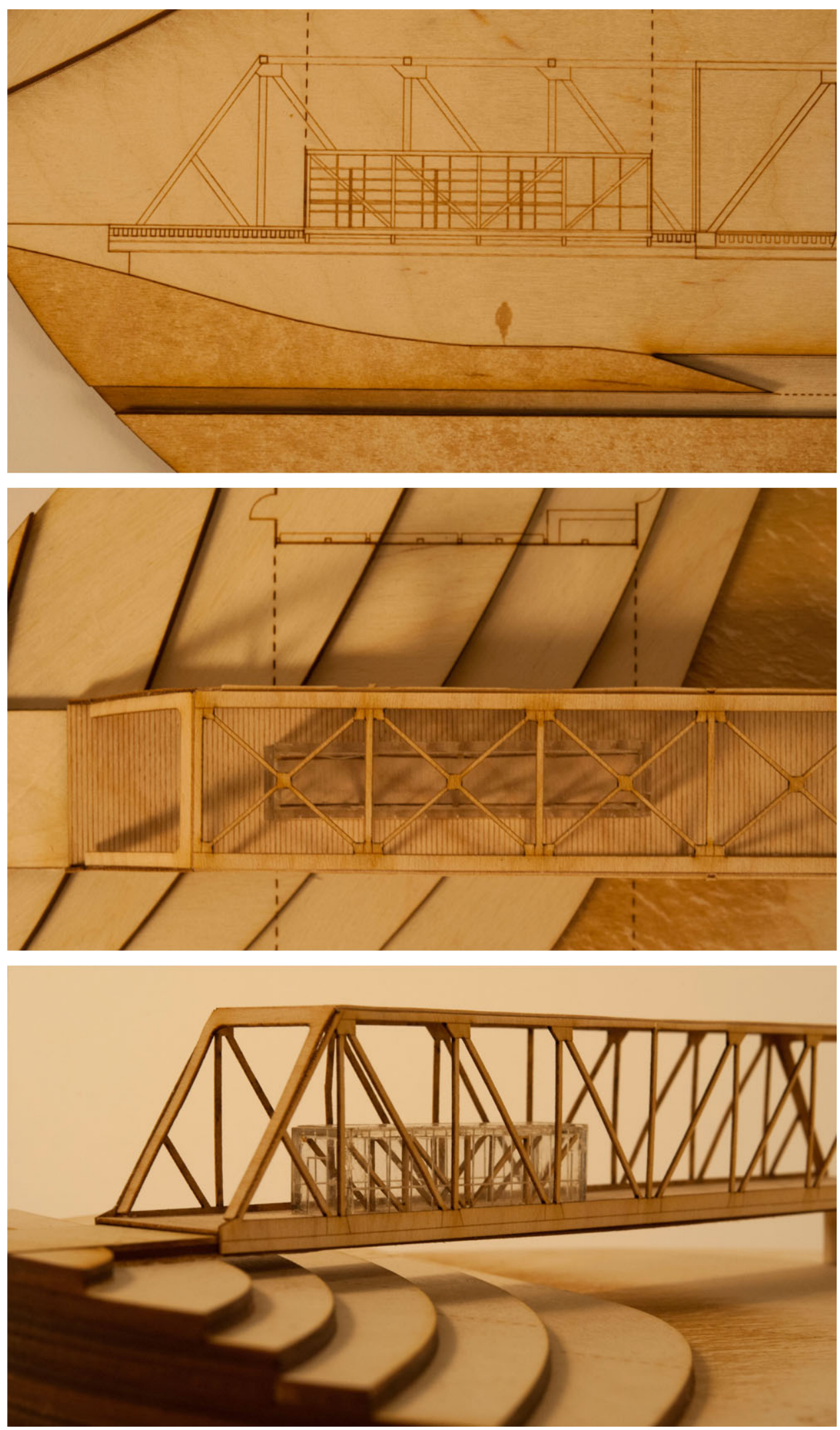

Appendix 8 - Construction 2 Model 

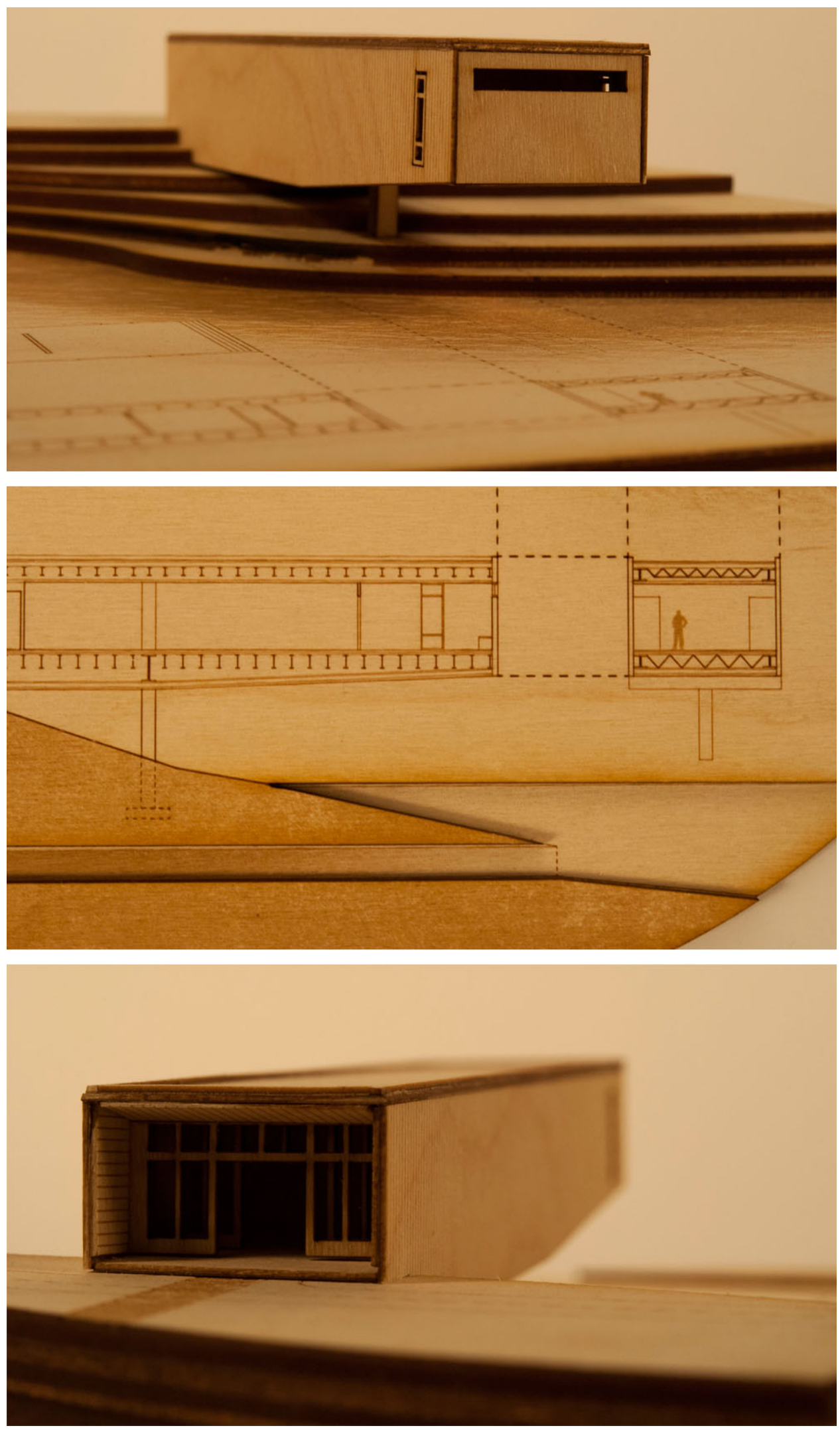

Appendix 9 - Construction 3 Model 

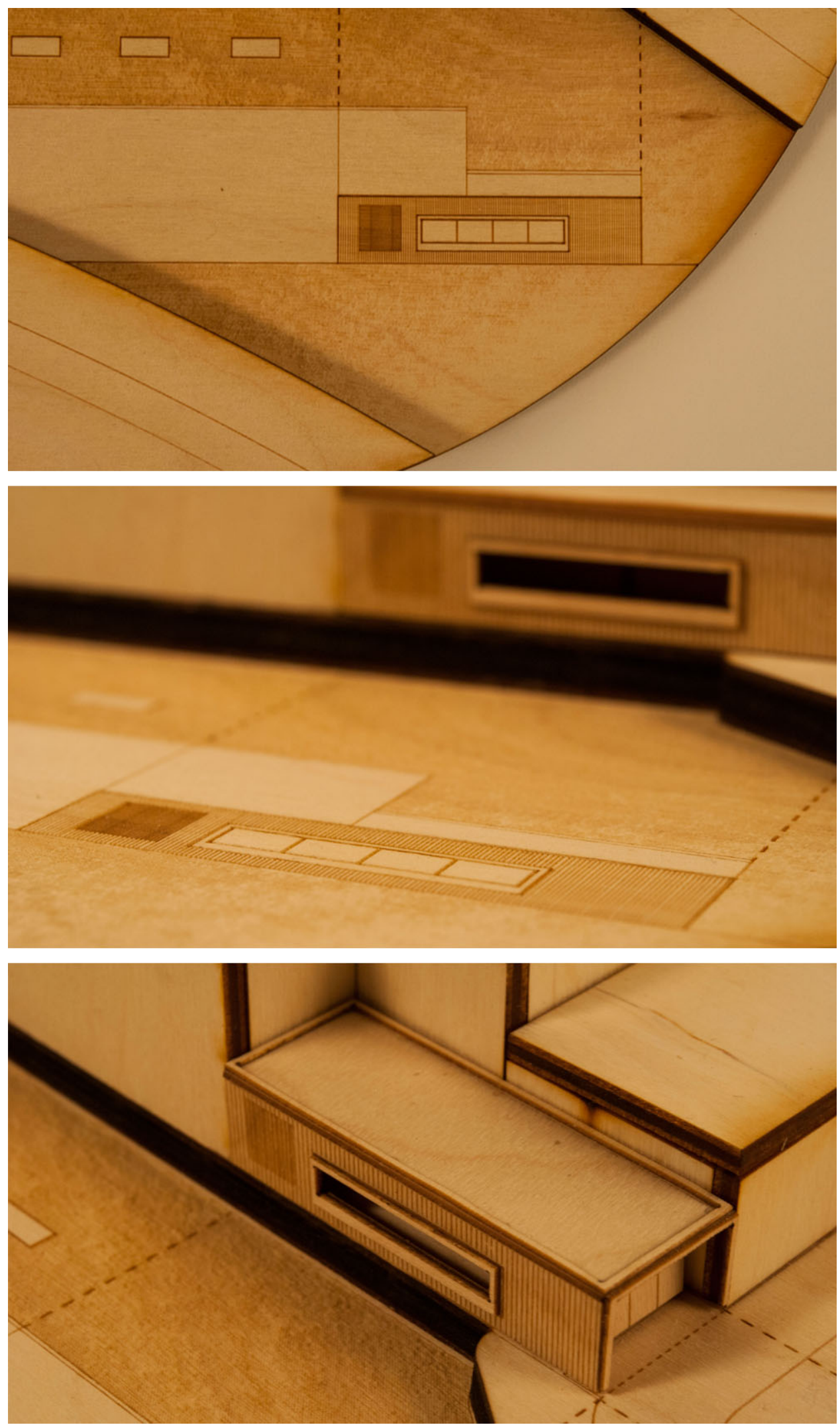

Appendix 10 - Construction 4 Model 

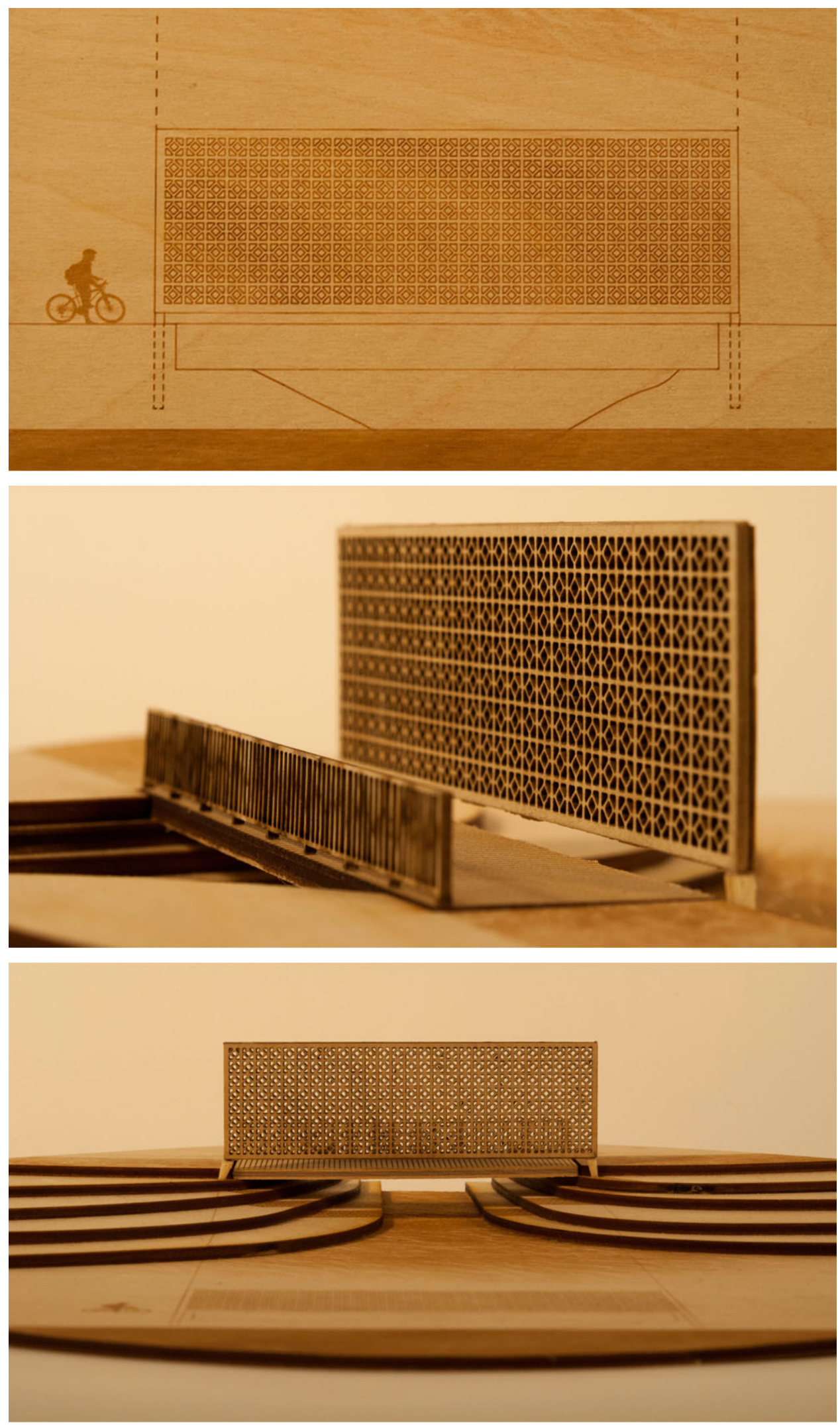

Appendix 11 - Construction 5 Model 

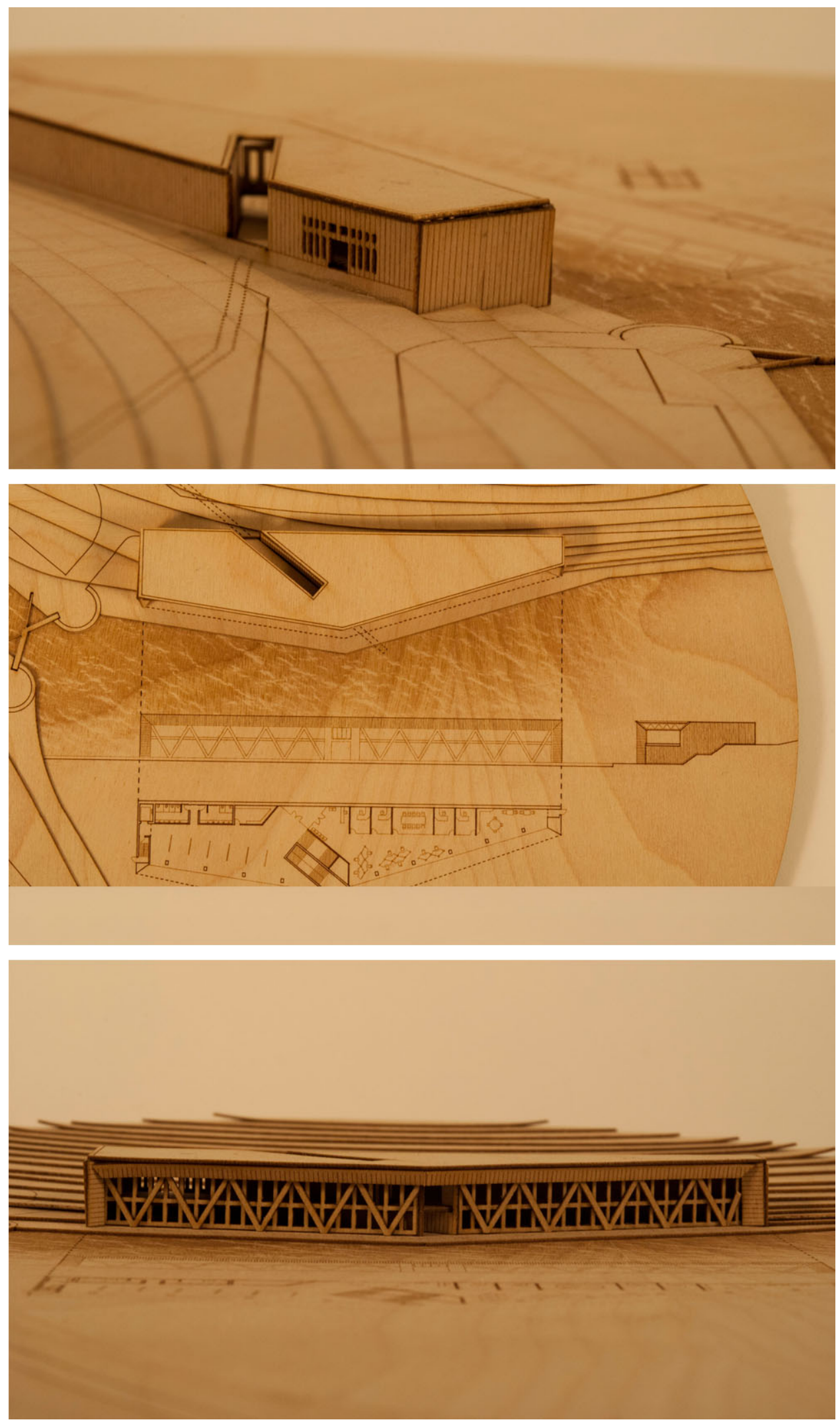

Appendix 12 - Construction 6 Model 

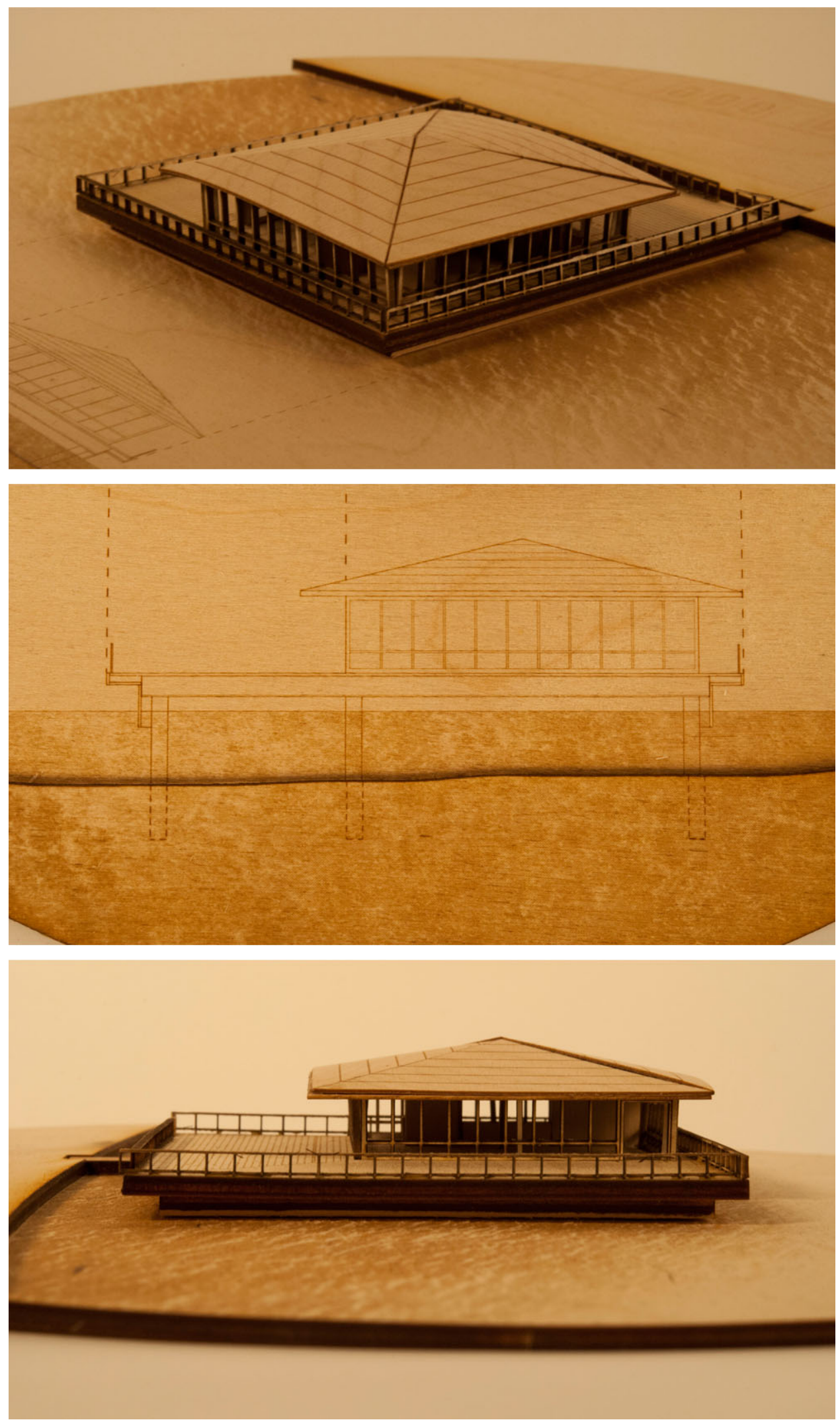

Appendix 13 - Construction 7 Model 

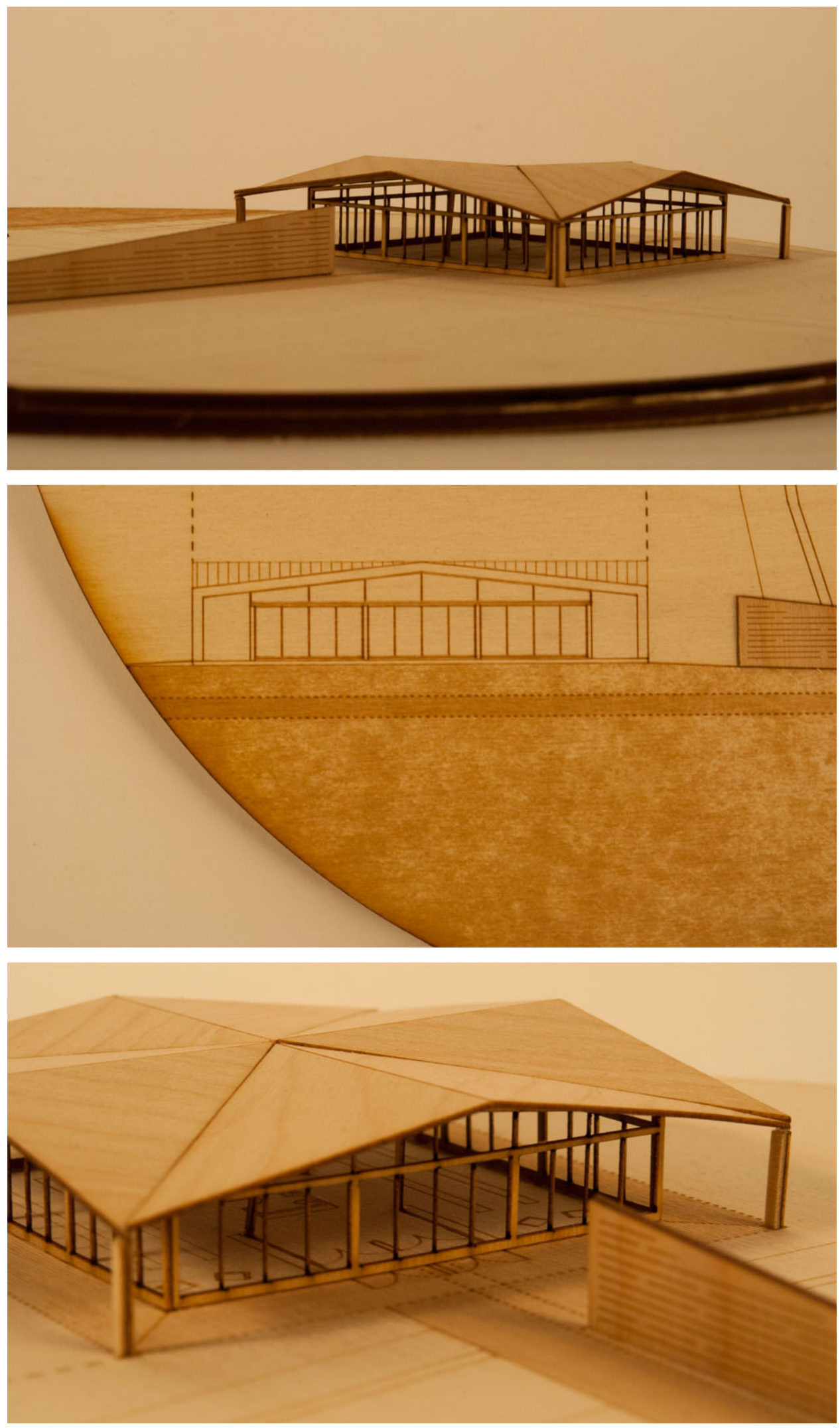

Appendix 14 - Construction 8 Model 

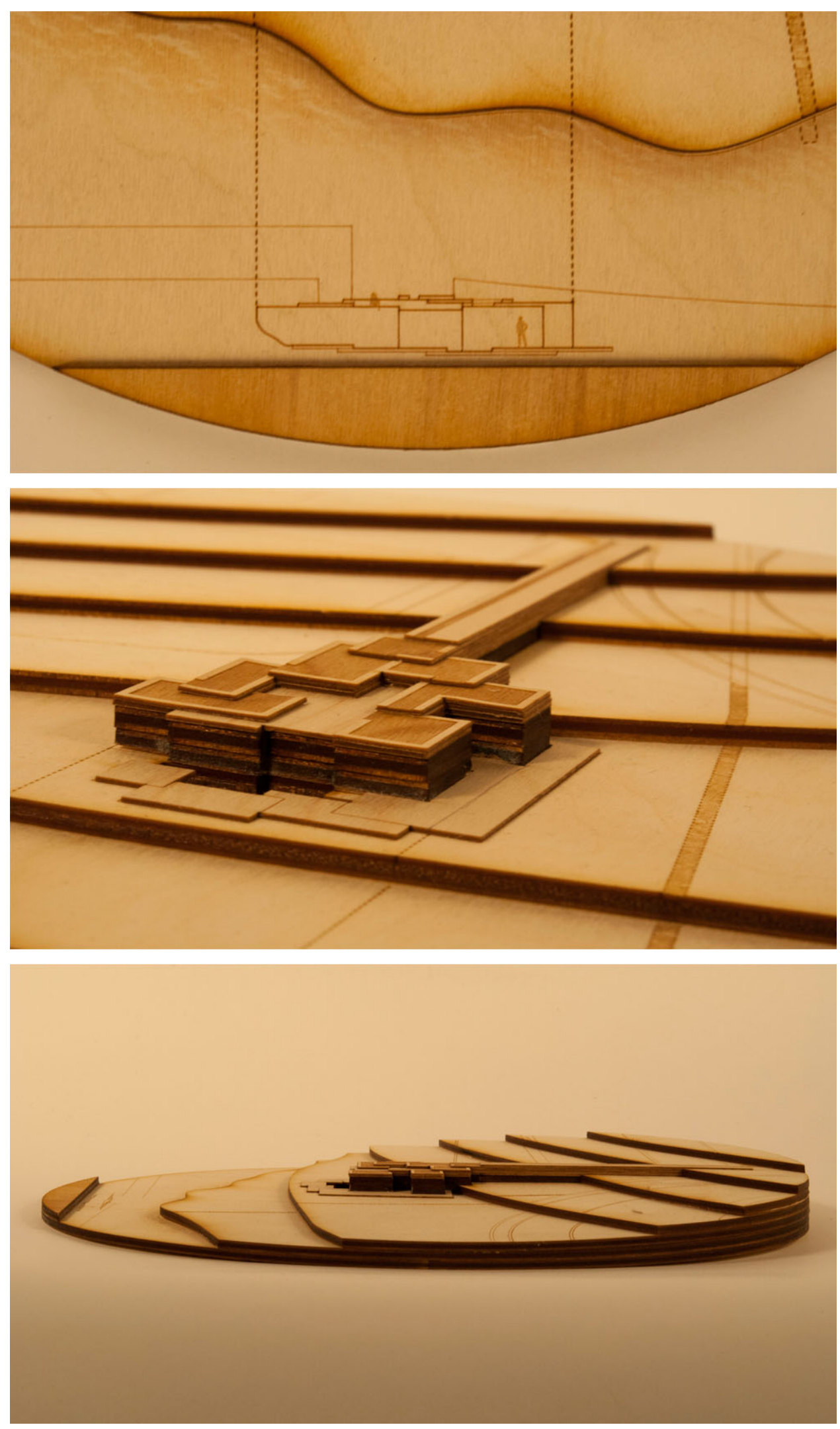

Appendix 15 - Construction 9 Model 

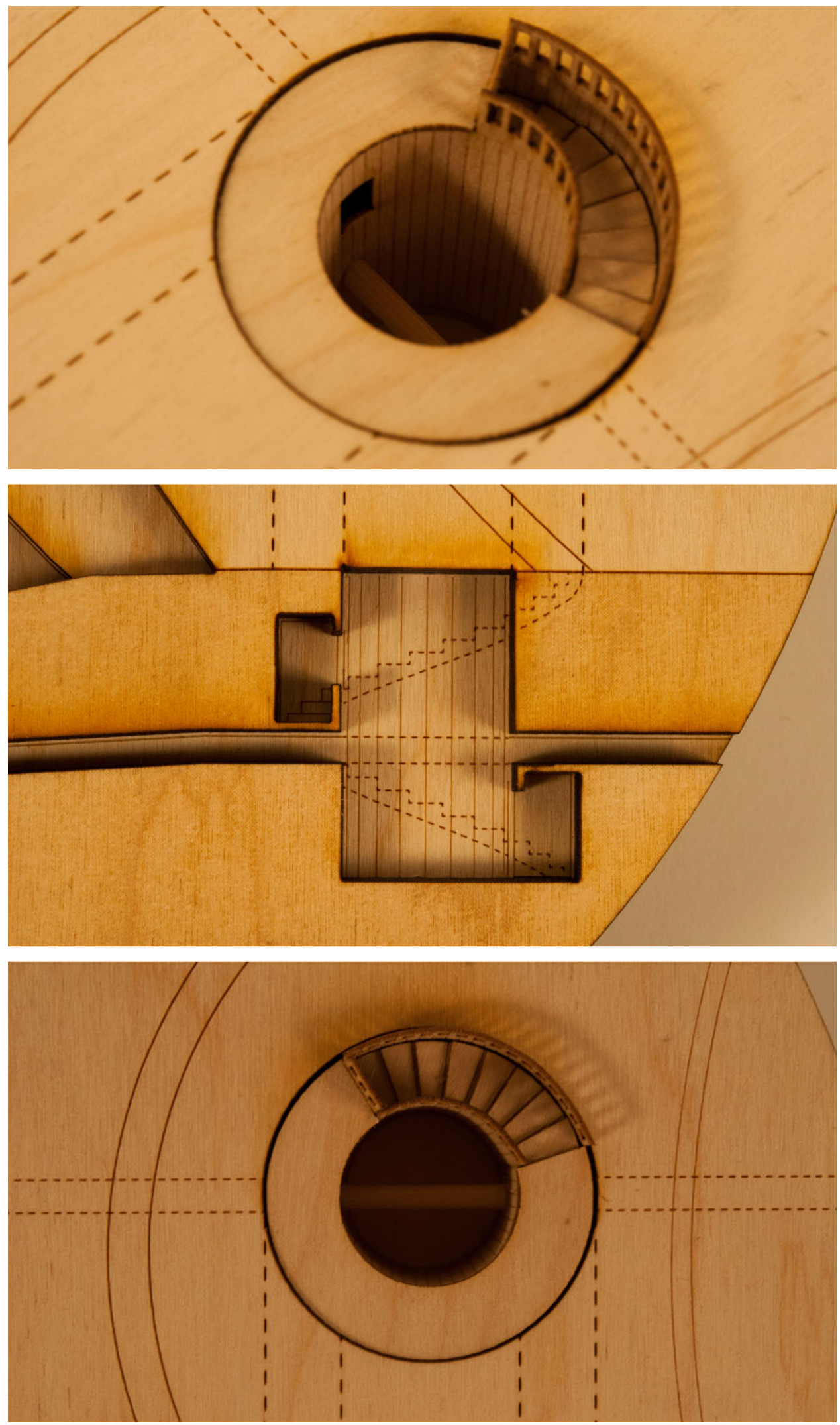

Appendix 16 - Construction 10 Model 

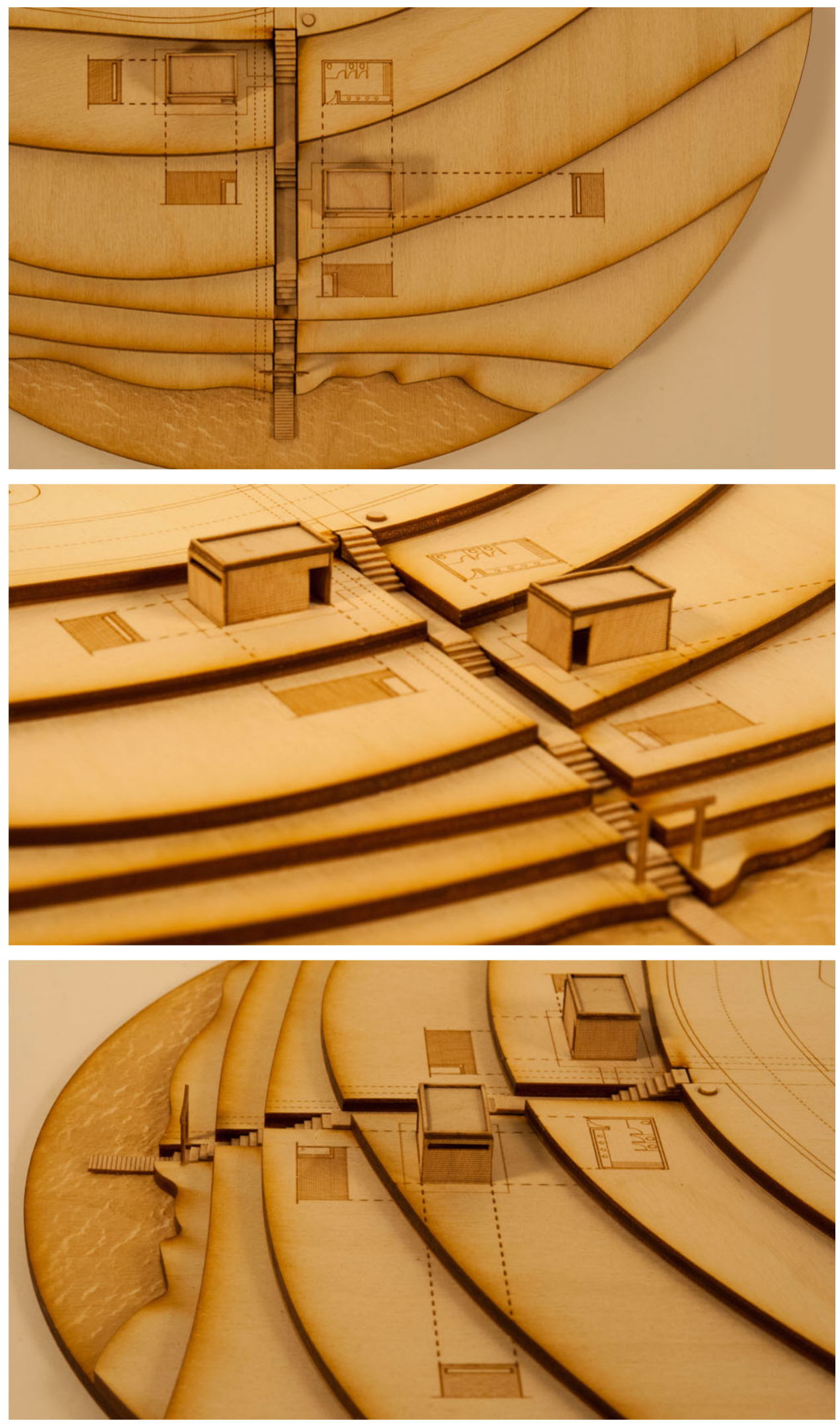

Appendix 17 - Construction 11 Model 

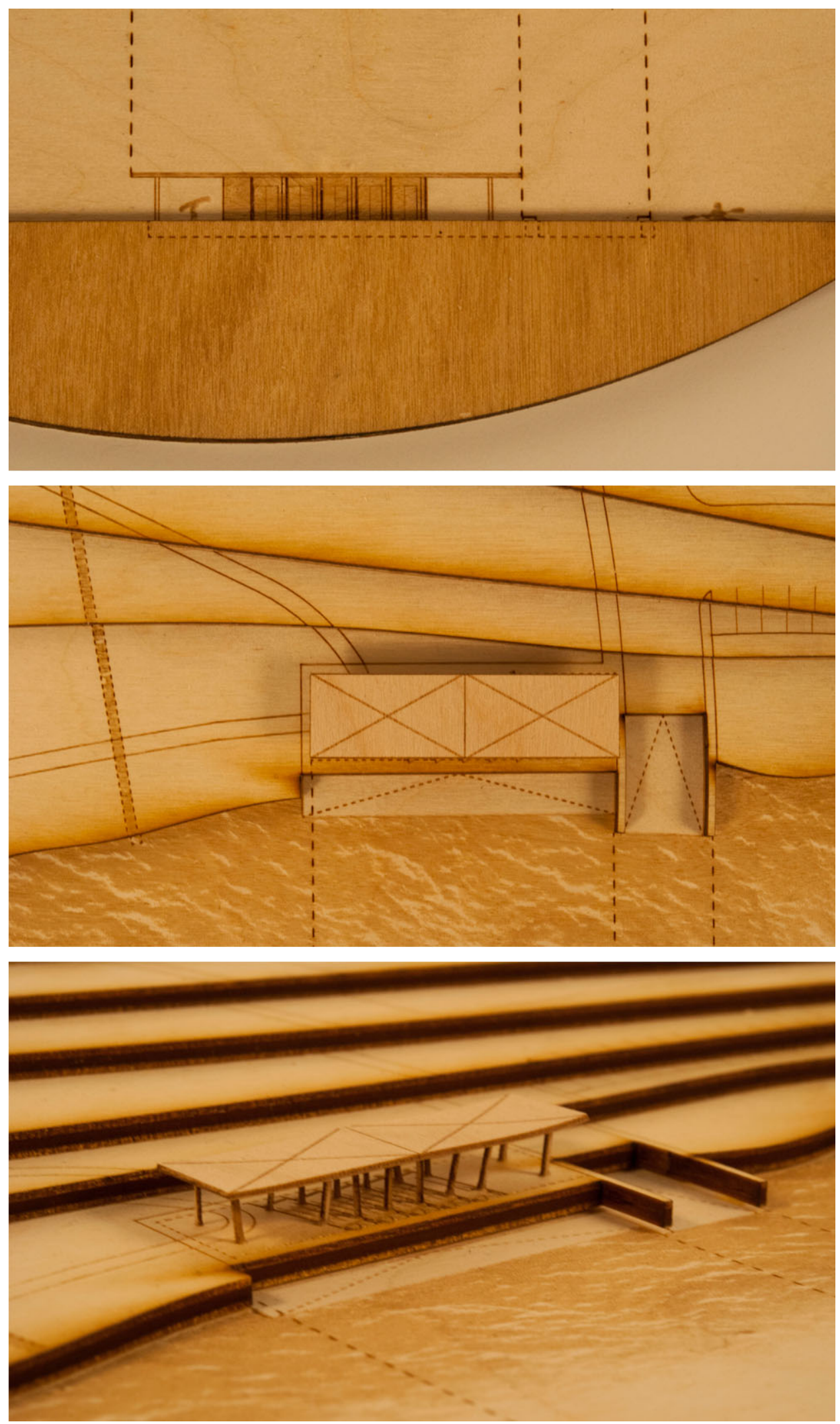

Appendix 18 - Construction 12 Model 

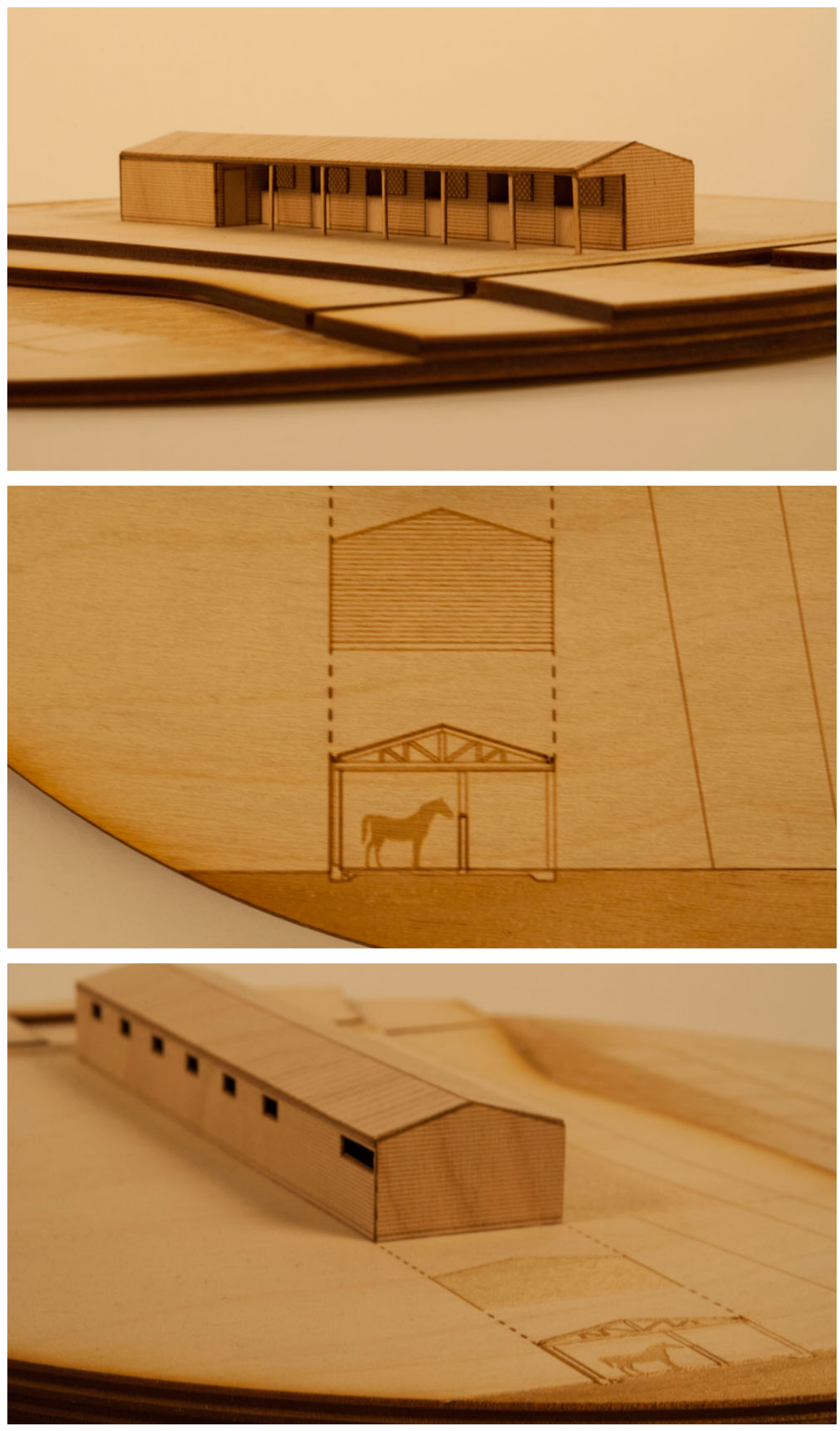

Appendix 19 - Construction 13 Model 

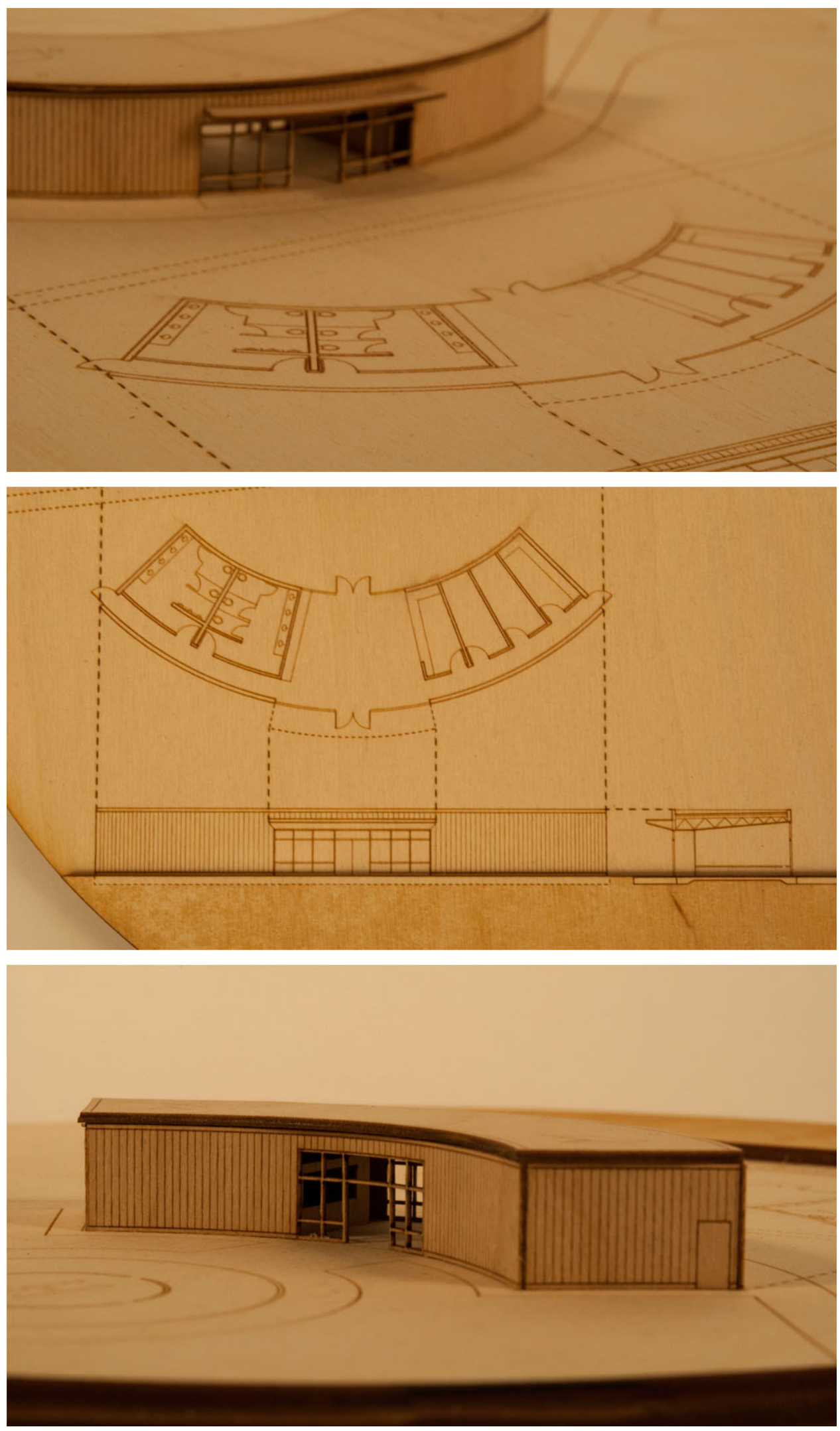

Appendix 20 - Construction 14 Model 

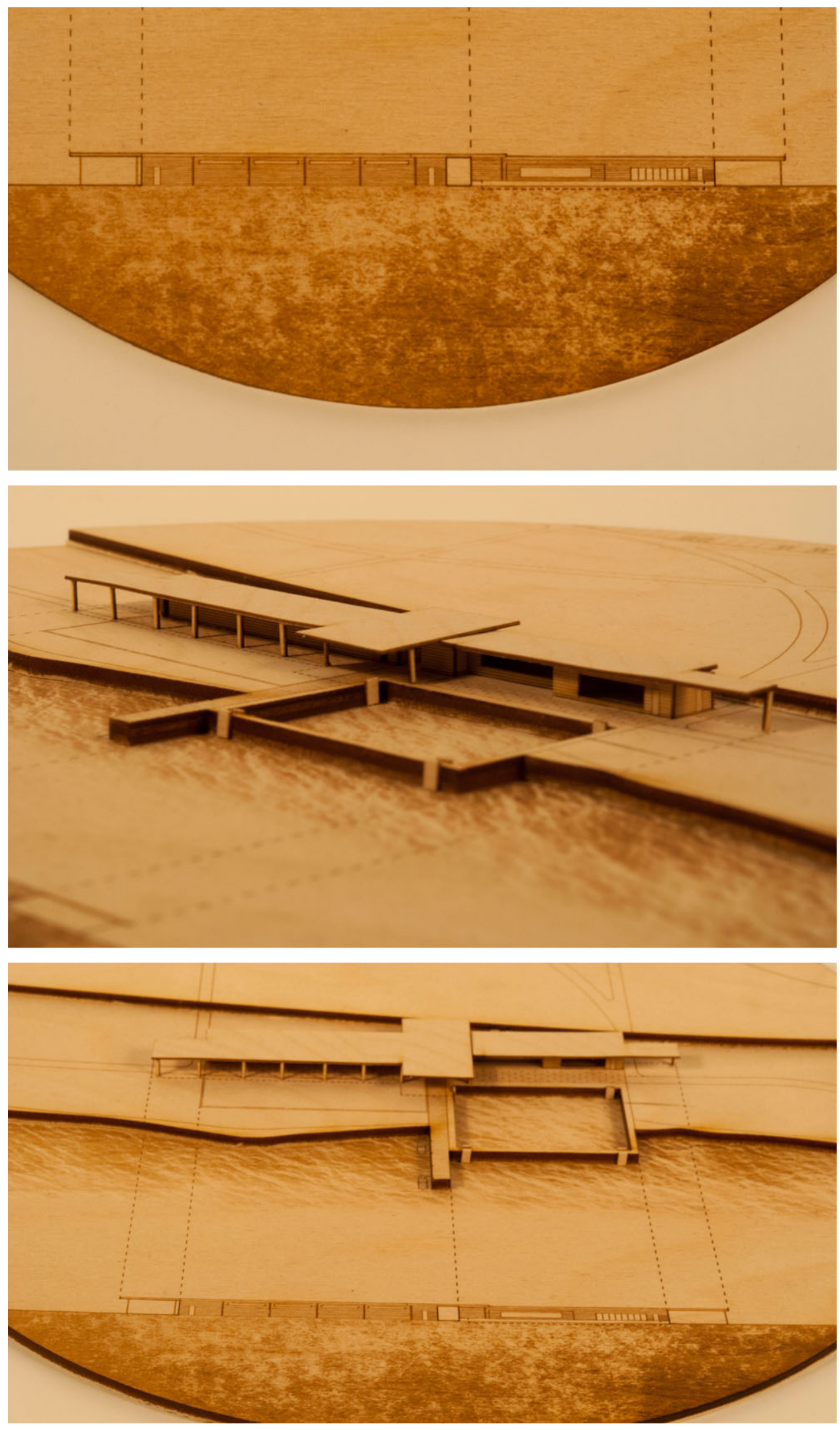

Appendix 21 - Construction 15 Model 

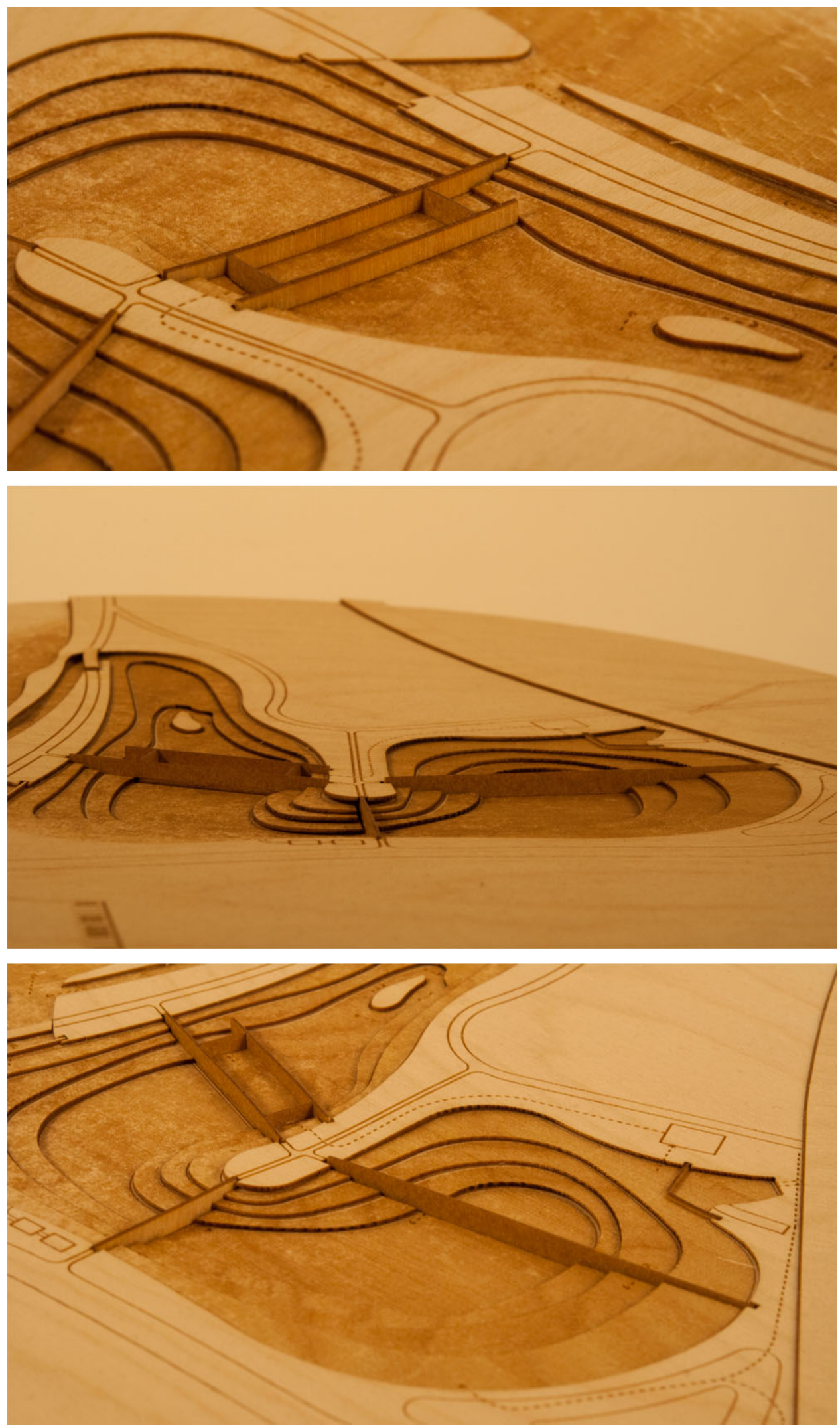

Appendix 22 - Construction 16 Model 


\section{Bibliography}

Aird, Louise. Dream Team: Architect Arthur Erickson \& Landscape Architect Cornelia Hahn Oberlander. June 1994. http://louiseaird.com/2013/07/03/dream-team-architect-arthur-erickson-landscapearchitect-cornelia-hahn-oberlander/. Accessed 15 Mar 2016.

Alternate Solution 5 - Dunker's System. Open House March/April 2009. City of Ottawa. 2009. http://ottawa.ca/en/city-hall/public-consultations/sewers-and-wastewater/open-house-marchapril2009. Accessed 10 Nov 2015.

Announcement of 2009 ULI Awards for Excellence. Urban Land Institute, Atlanta, April 24, 2009.

Attlee, James. Towards Anarchitecture: Gordon Matta-Clark and Le Corbusier. Tate Papers no.7. 2007. http://www.tate.org.uk/research/publications/tate-papers/07/towards-anarchitecture-gordon-mattaclark-and-le-corbusier. Accessed 15 Feb 2016.

Beach Closures. Ottawa Riverkeeper. 2015. http://www.ottawariverkeeper.ca/beach-closures/. Accessed 15 Nov 2015.

Carl Turner Architects. Small: thoughts and projects. Artifice books on Architecture. London. 2013.

Charleson, Andrew. Structure as Architecture: A Source Book for Architects and Structural Engineers. Elsevier/Architectural Press. 2005.

Churcher, Collin. 125th Anniversary of the Opening of the Prince of Wales Bridge. Bytown Railway Society. Branchline, Jan 2006. http://www.railways.incanada.net/Articles/Article2006_01.html. Accessed 12 Feb 2016.

City-Owned Wells and Purification Plants. City of Ottawa. 2015. http://ottawa.ca/en/residents/water-andenvironment/drinking-water/water-purification-and-treatment-process. Accessed 12 Dec 2015.

Combined Sewage Storage - Environmental Study Report. City of Ottawa. Stantec. 8 Jan 2013. http://documents.ottawa.ca/sites/documents.ottawa.ca/files/documents/final_csst_esr.pdf. Accessed 15 Nov 2015.

Combined Sewer Overflows (CSOs). City of Ottawa. 2015. http://ottawa.ca/en/residents/water-andenvironment/sewers-and-septic-systems/combined-sewer-overflows. Accessed 15 Dec 2015.

Dal Co, Francesco. Carlo Scarpa: The Complete Works. Electa/Rizzoli. 2006.

Dattner, Richard. Civil Architecture: The New Public Infrastructure. McGraw-Hill Inc. USA. 1 Jan 1995.

Duffy, Jim. 100 Years: Baltimore Gets a New Downtown. Baltimore Magazine. Nov 2007. http://www.baltimoremagazine.net/old-site/features/2007/11/100-years-the-twelve-events-thatshaped-baltimore. Accessed 20 Mar 2016.

Dümpelmann, Sonja, Beardsley, John B. Women, Modernity, and Landscape Architecture. Routledge. 11 Feb 2015.

E. coli. Public Health Agency of Canada. 20 Oct 2015. http://www.phac-aspc.gc.ca/fs-sa/fs-fi/ecolieng.php. Accessed 15 Nov 2015.

Fleet Street Pumping Station (Ottawa), 1874-75. Ontario Heritage Trust. 2016. http://www.heritagetrust.on.ca/Conservation/Conservation-easements/Visit-our-easementproperties/Ottawa/Fleet-Street-Pumping-Station-(Ottawa),-1874-75.aspx. Accessed 5 Jan 2016.

Fortier, Claudine and Mailhot, Alain. Climate Change Impact on Combined Sewer Overflows. 2014.

Gastil, W, Raymond. Beyond the Edge: New York's New Waterfront. Van Allen Institute. Princeton Architectural Press. New York. 2002. New public American Society of Civil Engineers. 
Gaventa, Sarah. New Public Spaces. Mitchell Beazley. Octopus Publishing Group. Great Britain. 2006.

Gréber, Jacques. Plan For The National Capital. 1950.

Greenberg, Stanley. Waterworks: A Photographic Journey Through New York's Hidden Water System. Princeton Architectural Press. New York. 2003.

Hugo, Victor. Les Misérables Volume Two. Woodsworth Editions Limited. 1994.

Lopate, Phillip. Waterfront: A Walk Around Manhattan. Knopf Doubleday Publishing Group. New York. 2008.

Millspaugh, Martin L. The Inner Harbor Story. Urban Land Magazine. April 2003.

Monson, Ander. Other Electricities: Stories. Sarabande Books. Michigan. 2005.

Moore, Holly. Drinking Water in Canadian Cities Not Always Tested for All Contaminants. CBC News. 19 Jun 2015. http://www.cbc.ca/news/canada/manitoba/drinking-water-in-canadian-cities-notalways-tested-for-all-contaminants-1.3111908. Accessed 12 Feb 2016.

M. Lee, Pamela. Object to be Destroyed: The Work of Gordon Matta-Clark. MIT Press. 2001.

Murg, Stephanie. Gordon Matta-Clark: Cutting through History. Metropolis. 10 Aug 2013. http://www.metropolismag.com/Point-of-View/April-2013/Gordon-Matta-Clark-Cuttingthrough-History/. Accessed 16 Feb 2016.

Performance Assessment of a Flow Balancing and Wetland Treatment System - Toronto, Ontario. Sustainable Technologies Evaluation Program. 2016.

http://www.sustainabletechnologies.ca/wp/home/urban-runoff-green-infrastructure/conventionalstormwater-management/flow-balancing-systems/performance-assessment-of-a-flow-balancing-andwetland-treatment-system-toronto-ontario/. Accessed 02 Feb 2016.

Project Overview. Combined Sewer Overflow (CSO) Storage Environmental Assessment and Functional Design Project. City of Ottawa. 2015. http://ottawa.ca/en/city-hall/public-consultations/sewersand-wastewater/project-overview. Accessed 6 Dec 2015.

Promenade Samuel-de Champlain. Canadian Architect. 1 May 2010.

Residential Water Use in Canada. Environment and Climate Change Canada. 17 Feb 2016. https://www.ec.gc.ca/indicateurs-indicators/default.asp?lang=en\&n=7E808512-1. Accessed 2 Dec 2015.

Ryckbost, Paul. Redeveloping Urban Waterfront Property. 14 April 2005. http://www.umich.edu/ econdev/waterfronts/. Accessed 11 Mar 2016

Timur, Umut Pekin. Urban Waterfront Regenerations. Advances in Landscape Architecture. Chapter 7. Çankırı Karatekin University, Faculty of Forestry. 1 Jul 2013.

Wastewater Services. City of Ottawa. 2015. http://ottawa.ca/en/city-hall/accountability-andtransparency/corporate-planning-and-performance-management/wastewater-1. Accessed $20 \mathrm{Mar}$ 2016.

Water Quality Archives. Friends of Petrie Island. 7 Sep 2015. http://www.petrieisland.org/water-qualityarchives. Accessed 15 Nov 2015.

Water + Architecture. University of California, Berkeley. http://waterarc.ced.berkeley.edu/. Accessed 14 Dec 2015.

Williams, Robert. Presence \& Absence: Carlo Scarpa, Querini Stampalia, \& Water. 3SIXØ Architecture. 23 Jul 2009. http://3six0.com/thoughts/presence-absence-carlo-scarpa-querini-stampalia-water/. Accessed 15 Mar 2016. 